\title{
Mixed views about radical life extension
}

\author{
Allen Alvarez ${ }^{1}$, Lumberto Mendoza ${ }^{2}$, \& Peter Danielson ${ }^{3}$ \\ ${ }^{1}$ Department of Philosophy \& Religious Studies, Norwegian University of Science and \\ Technology, Trondheim, allen.alvarez@ntnu.no \\ ${ }^{2}$ Department of Philosophy, University of the Philippines Diliman, \\ lumberto.mendoza@up.edu.ph \\ ${ }^{3}$ Centre for Applied Ethics, School of Population \& Public Health, University of British \\ Columbia, Vancouver, Canada, danielsn@exchange.ubc.ca
}

(cc) BY

This is an open access article distributed under the terms of the Creative Commons Attribution 4.0 International License, which permits unrestricted use, distribution, and reproduction in any medium, provided the original author and source are credited.

Recent studies on public attitudes toward life extension technologies show a mix of ambivalence toward and support for extending the human lifespan (Partridge 2009; Dragojlovic 2013; Funk et al. 2013). Attitudes toward technological enhancements may be used to categorize individuals according to political or ideological orientation such as technoprogressive or conservative (Hughes 2010) and it could be easy to assume that these categories are related to more general categorizations related to culture, e.g. between Traditional and Secular-rational values in the World Values Survey (Ingelhart \& Welzel 2010). This paper discusses how attitudes toward aspects of radical life extension may be related to cultural values as revealed in an online deliberative survey among university students conducted between January 2012 to January 2013. Survey results suggest that attitudes toward radical life extension tend to be mixed among groups categorized as Traditional, Secular-rational, Survivalist, and Self-expressionist. The study explored the relation between responses of 326 university students to 5 key questions on radical life extension (RLE) and the cultural values they tend to favor as indicated by their response to 20 statements from the World Values Survey.

Design and Method: The survey consisted of 3 stages: an online pre-discussion survey, face-to-face discussion, and post-discussion survey. After completing the 5 main survey questions in stage 1 , participants were presented two additional questionnaires: one on cultural attitudes using 20 statements from the 2004-2008 World Values Survey (WVS) and another on health attitudes with 12 statements from Dutta-Bergman's 2004 study. In stage 2, participants were engaged in a face-to-face discussion in class focusing on their responses to the five key questions. After the discussion, they were invited to reconsider the choices and reasons they posted in stage 1 in the light of the face-to-face class discussion in stage 2.

Results: Responses to the five survey questions showed that there tended to be more individuals across groups who disagreed with adopting technologies that radically extend the human lifespan beyond the current limit of 120 years. Attitudes toward radical life extension did not correspond to cultural attitudes indicated by responses to the WVS questions. The proportion of agreement/disagreement to statements presented in each of the five questions varied across cultural groups and there tended to be more individuals who disagreed with radical life extension in all groups. Changes in responses after the discussion stage were not significant and most respondents maintained their prior views.

Discussion: Cultural attitudes associated with familiar technologies may not correspond with attitudes toward newer technologies since beliefs and values may need to be adapted to new imagined situations that the new technologies elicit. Moral understandings associated with familiar technological habits and beliefs are not necessarily carried over to new technologies.

Keywords: Radical life extension ethics, online deliberative survey, cultural values 


\section{Introduction}

A number of studies have explored public attitudes toward life extension technologies. A telephone interview survey conducted among 605 members of the Australian public reveals ambivalence on the issue of extending the human lifespan (Partridge, Lucke, Bartlett, \& Hall, 2009). A recent study conducted in 2012 among the Canadian public suggests that moderate life extension of up to 120 years is supported by 59\% of 1,231 survey participants (Dragojlovic, 2013). That recent study also suggests that individuals' general orientation towards science and technology may strongly predict support for radical life extension. In another recent (2013) study conducted among 2,012 nationally representative cohorts in the United States by the Pew Research Center, 51\% said that radical life extension (RLE) would be a bad thing for society while $41 \%$ said that it would be a good thing (Funk et al., 2013). Since the prospect of extending healthy human lifespan beyond 120 years is still a very controversial issue, it would be informative to explore how the cultural values or attitudes of the public are related to their views about RLE, i.e. their support for or rejection of the prospect of radically extending healthy human lifespan. Our current study explored the relation between responses of 326 university students to five key questions on RLE and their cultural attitudes as indicated by their responses to 20 statements derived from the World Values Survey.

\section{Design and Method}

An online deliberative survey among university students using the "N-Reasons platform" (Danielson, 2010) was conducted between January 2012 and January 2013. The aim of the survey was to explore attitudes to RLE and compare cultural attitudes with responses to five main survey questions related to biomedical research in RLE, means of life extension, effects of RLE on global population growth, compatibility of deeply held beliefs with RLE and interest in using RLE in advanced years. (See Appendix 1 for details of the five main survey questions). The survey consists of three stages (see Fig. 1 below). In stage 1, five main survey questions were asked. Prior to asking each question, a paragraph (authored by Alvarez) discussing relevant information on life extension research was presented with web links to relevant journal articles. In the invitation page (which was part of stage 1), web links to two journal articles were also provided (in particular, a link to the article by Jim Oeppen and James Vaupel, published in Science in 2002, arguing that life expectancy continues to increase; another by Aubrey de Grey, published in Experimental Gerontology in 2003, criticizing arguments for rejecting foreseeability and desirability of anti-aging medicine $)^{1}$. In survey question 1, the first sentence about life expectancy included links to a web article showing current life expectancy averages around the world and a New York Times article reporting the death of the world's oldest person, Jeanne Calment. ${ }^{2}$ In survey question 3 , web links to two articles were provided, one ${ }^{3}$ supporting the idea that overpopulation could result from using RLE while another ${ }^{4}$ showing the opposite. In survey question 4 , a web link was provided to an article citing surveys around the world indicating that many elderly people want to be resuscitated. ${ }^{5}$ After completing the five main survey questions, participants were then presented two additional questionnaires: one on cultural attitudes using 20 statements from the World Values Survey (WVS) ${ }^{6}$ and another on health attitudes using 12 statements from Dutta-Bergman's 2004 study (see Appendix 3 for details).

In stage 2, participants (who were members of a university class) were then engaged in a face-to-face discussion with their fellow students and facilitating instructors (Alvarez, Mendoza and Evangelista $)^{7}$ focusing on the five main questions. They were then invited to 
take the survey a second time in stage 3 to reconsider their choices and the reasons they posted, giving them the opportunity to change these in the light of the class discussion in stage 2 .

\section{Participant Recruitment}

Eleven classes were recruited from four universities in Norway and the Philippines, including two public cohorts with participation by students from Canada and public participants who discovered the survey site on the Web. Our participant recruitment follows what is called a non-probability/accidental or convenience sampling technique. We do not claim that the results are generalizable to the population (or country) from which the participants came. Most of the participants who are members of the 11 classes were asked to participate in all three stages of the survey where two of the authors (Alvarez and Mendoza) and one university professor facilitated the face-to-face discussion stage. The classes that participated in Norway consisted of courses in technology and ethics and corporate social responsibility. Both classes consisted of a mix of students from natural sciences, engineering, social sciences and humanities, including philosophy. The classes from the Philippines consisted of two courses in critical thinking, five introductory courses in philosophy and two courses in science and technology studies (see Table 1). All classes consisted of a mix of students majoring in different study programs from the natural sciences, engineering, social sciences and humanities, including philosophy. There were 489 registered participants but only 326 were included in the analysis. One-hundred and sixty-three were excluded due to incomplete responses in the cultural attitudes questionnaire, which is key to addressing one of the main research question on how cultural attitudes relate to views about RLE. We excluded responses that contained inconsistent answers, where participants responded with Agree and Disagree on the same question. This was done using a quantitative analysis software command that automatically excluded those responses.

Figure 1. Three stages in the N-Reasons survey

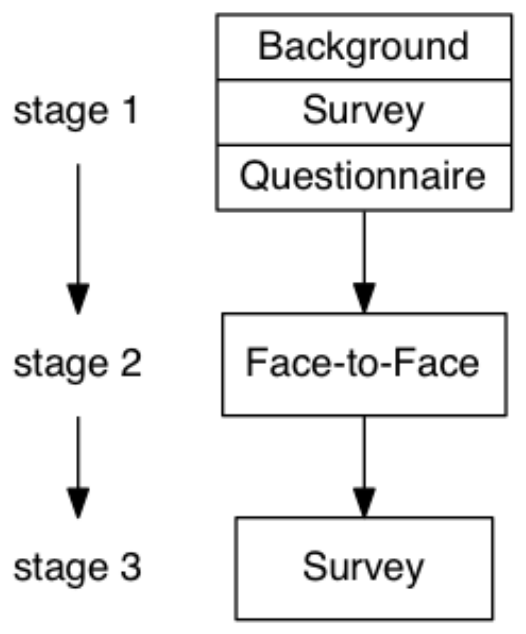

Table 1. List of participating classes

\begin{tabular}{rll}
\hline Class ID & Subject & Composition \\
\hline 20 & Not specified & public \\
30 & Not specified & public \\
31 & Technology and ethics & class \\
33 & Business ethics & class \\
43 & Reasoning & class \\
57 & Reasoning & class \\
74 & Introduction to philosophy & class \\
111 & Introduction to philosophy & class \\
112 & Introduction to philosophy & class \\
197 & Introduction to philosophy & class \\
198 & Introduction to philosophy & class \\
75 & Science and technology studies & class \\
113 & Science and technology studies & class \\
\hline
\end{tabular}


The classes that had face-to-face discussions in stage 2 were shown a short video (seven minutes) on life extension ${ }^{8}$ followed by a discussion of the reasons for and against RLE technologies. All classes that had face-to-face discussions were invited to take the survey again in stage 3 to reconsider the choices and reasons they posted.

Members of the public who discovered the survey site on the Internet or were referred to the survey by their contacts were randomly assigned to the listed classes but were marked in the data tables for exclusion. This mechanism of random assignment of public participants to classes is part of the general design of most N-Reasons surveys to enhance anonymity of responses when participants post reasons.

\section{Results}

\section{Quantitative Analysis Aggregated by Question}

The aggregated results of all classes indicate a tendency to disagree with statements suggesting that RLE be adopted. Regarding the question on whether RLE is a desirable goal for biomedical research (see Chart 1), 50\% disagreed (including 4\% who strongly disagreed) versus $13 \%$ who agreed ( $11 \%$ strongly) and $37 \%$ neutral. When asked if they would avail themselves of RLE in their old age (Chart 1), 56\% were neutral and 39\% disagreed $(26 \%$ strongly) versus $5 \%$ who agreed ( $4 \%$ strongly). Seventy-nine percent disagreed ( $59 \%$ strongly) that RLE is compatible with their deeply held beliefs.

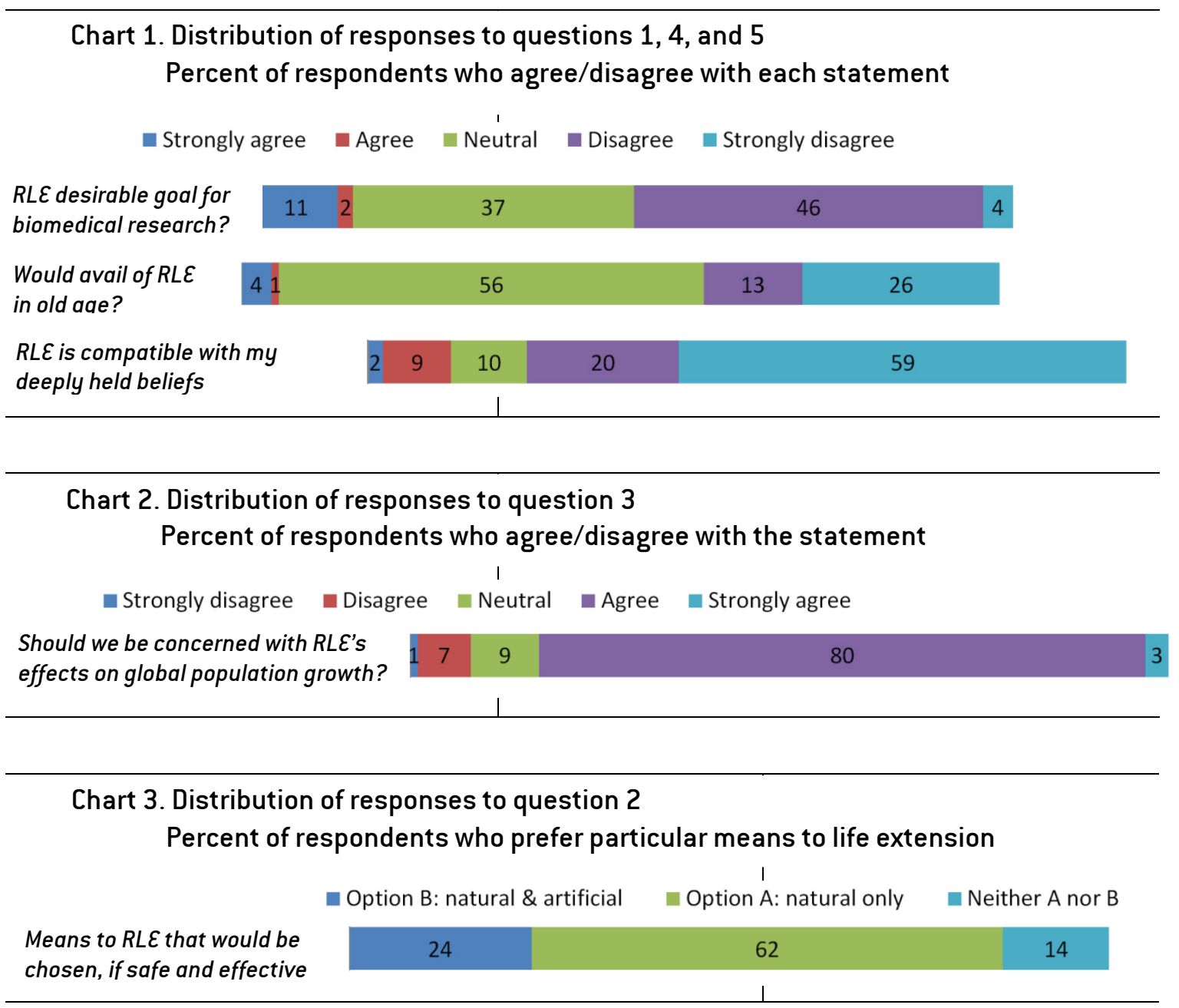


The overall response to the question related to effects on global population growth (see Chart 2) shows that $83 \%$ agreed (including 3\% who strongly agreed) that we should be concerned with RLE effects on population growth versus $8 \%$ who disagreed ( $1 \%$ strongly) and 9\% who were neutral.

Regarding the hypothetical question about which safe and effective method of RLE participants would prefer (see Chart 3), $14 \%$ seem to reject any method versus $24 \%$ who are willing to use combined natural and artificial methods and an overwhelming $62 \%$ who insisted on using only natural means to life extension.

\section{Participants' cultural values and their responses to survey questions}

The World Values Survey (WVS) (Inglehart \& Welzel, 2010) has been used in other studies to classify the different cultural attitudes of different populations around the world. Four cultural values are paired in two dimensions/continuum in the WVS. These paired values are mapped in such a way that the Traditional versus Secular-rational values are graphed on the $y$-axis and the Survival versus Self-expression values on the $\mathrm{x}$-axis. The values that respondents of the WVS tend to favor can then be mapped where the two dimensions intersect (see WVS wave 5 (2004-2008) in Fig. 2 below).

Our survey adopted four cultural categories from the WVS as a proxy to describe cultural attitudes by which our survey participants could be grouped. This was not meant to test generalizable theses similar to those made in the original WVS. The 20 statements from the WVS (see Appendix 2) are presented in the survey to ask which cultural values participants are inclined to favor as indicated by a five-point Likert scale (strongly agree, agree, neutral, disagree, strongly disagree).

As presented in the 20 statements, those who favor Traditional values reject divorce, abortion, euthanasia and suicide, and tend to have high levels of national pride and a nationalistic outlook, value religion, parent-child ties, submission to authority and traditional family. Could it be possible that those who have these attitudes would tend to reject RLE as well?

Figure 2. World Values Survey Wave 5 (2004-2008) Cultural Map of the World ${ }^{9}$

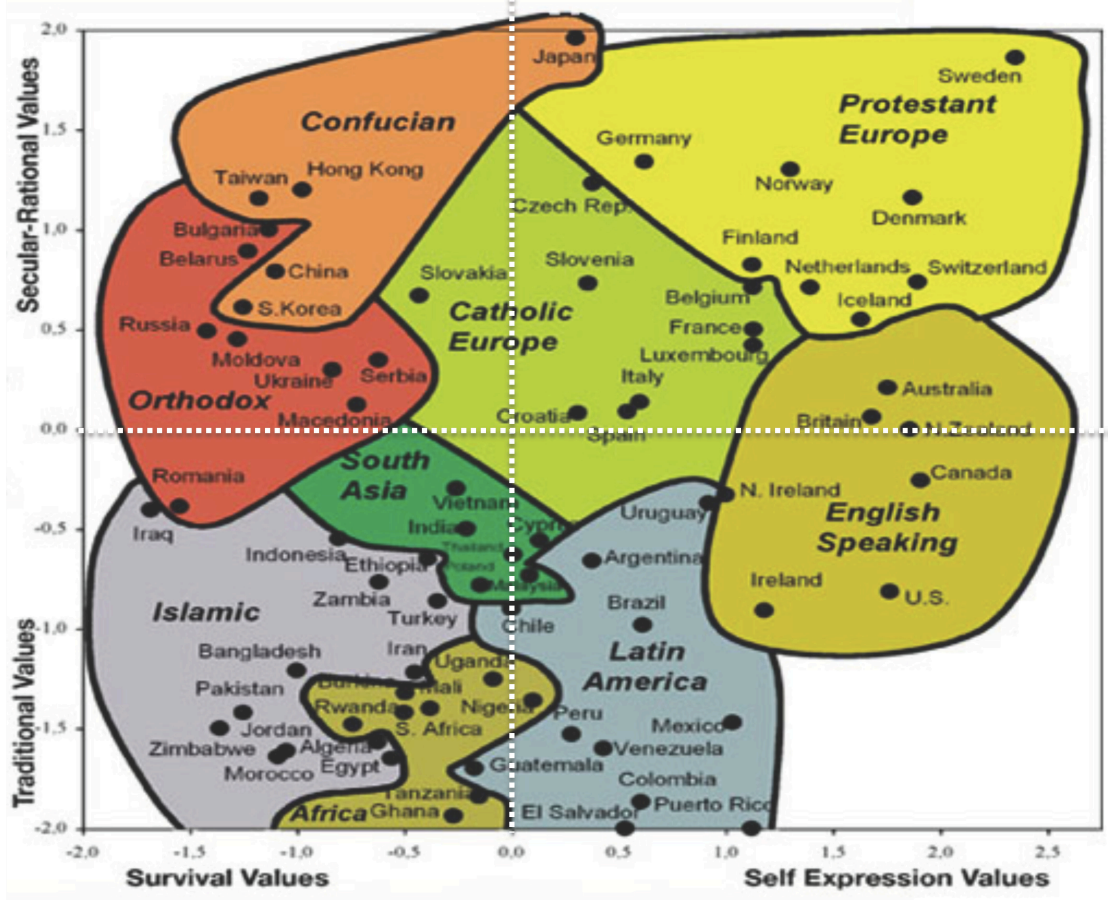


Those who favor Secular-rational values give less importance to religion, authority, and traditional family values and tend to accept divorce, abortion, and euthanasia. Could it be possible that those who have these attitudes would tend to approve RLE parallel to their openness to new ways of doing things?

Those who favor Survival values give importance to economic and physical security, tend to be ethnocentric in outlook, and have low levels of trust and tolerance. It is not obvious what sorts of attitudes towards RLE are related to these values.

Those who favor Self-expression values prioritize protecting the environment, inclined to be involved in policy decisions in economic and political affairs, and give importance to gender equality and being more and more tolerant of foreigners, gays and lesbians. It is also not obvious what sorts of attitudes to RLE are related to these values since the tendency to protect the environment might correspond to rejection of RLE as possibly resourcedemanding, while being tolerant to differences may possibly suggest openness to new technologies.

We categorized the responses to the 20 statements and the results showed that $43 \%$ of our survey participants favored the combination of Traditional and Survival values, $36 \%$ a combination of Traditional and Self-expression values, $19 \%$ a combination of Secular-rational and Self-expression values, and only $2 \%$ favored a combination of Secular-rational and Survival values. We also grouped the responses separately into the four categories (see Table 2) and observed that in the Traditional and Survival values dimension $78 \%$ of all the 326 participants favored Traditional values and only $22 \%$ favored Secular-rational values. The same group of participants had 54\% who favored Survival values and $46 \%$ who favored Selfexpression values in the Survival values versus Self-expression dimension.

Table 2. Distribution of participants according to preferred cultural values

\begin{tabular}{llr}
\hline Dimension & Preferred cultural values & Individuals \\
\hline \multirow{2}{*}{ 1. Traditional vs. secular-rational } & Secular-rational & 70 \\
& Traditional & 256 \\
\hline & & Total of 326 \\
\hline \multirow{2}{*}{ 2. Survival vs. self-expression } & Self-expression & 177 \\
& Survival & 149 \\
\hline & & Total of 326 \\
\hline
\end{tabular}

We created a scatter-plot chart of the cultural values favored by survey participants (see Fig. 3) to illustrate how this would situate their responses on the WVS cultural map. The numbers on each axis correspond to the equivalent score for all the responses to the 20 statements (see Appendix 2).

We tested the relation between the cultural values of participants and their responses to the survey questions. One hypothesis we tested is that the more participants favored traditional and/or survival values the more they would disagree with using RLE, and the more they favored Secular-rational and/or Self-expression values the more they would agree with using RLE. Surprisingly, however, there were those who strongly favored Secular-rational and/or Self-expression values but who also disagreed with adopting RLE technologies. There were those who strongly agreed with Traditional and/or Survival values but also agreed with 
using RLE. There could be more fine-grained variations in between extremes, of course. To account for such fine-grained variations, we superimposed a slope-like series of shaded areas on the scatter-plot chart to indicate the cultural attitudes versus response to each of the five questions. The series of shaded areas suggests that the more Secular-rational values were preferred, the more biomedical research on RLE would be agreeable (see Fig. 4, for example). The same figure, however, show that this prediction does not necessarily hold true because some of those who selected Traditional values, like those who selected Secular-rational values, also strongly agreed with pursuing biomedical research on RLE. Similar observations were made in all cultural categories for each of the four other questions (see Figs. 5 - 13).

Figure 3. Cultural Attitudes Map of Survey Participants. $\mathrm{N}=326$

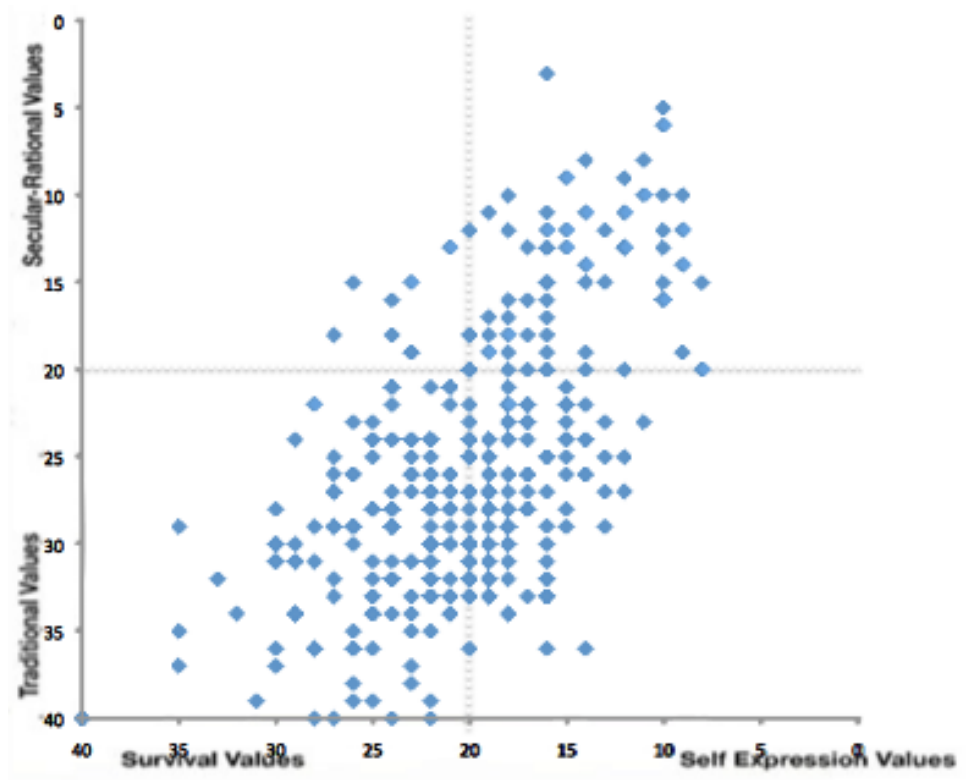

Figure 4. Question 1 decisions and Traditional vs. Secular-rational dimension 1 1. Is RLE a desirable goal for biomedical research?

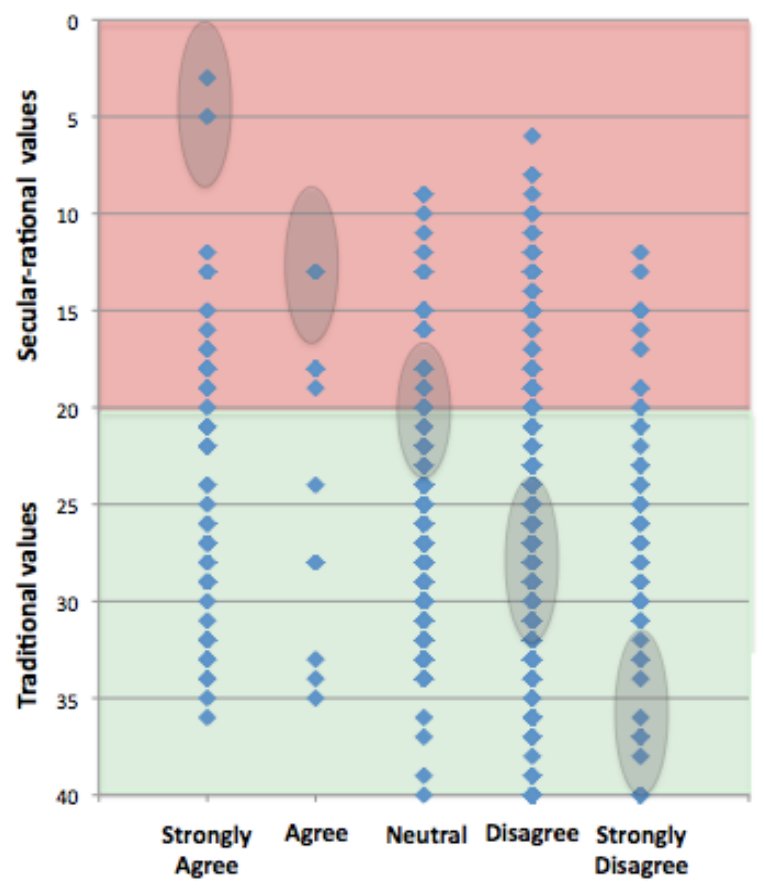

Figure 5. Question 1 decisions and Survival vs. Self-expression dimension. 1 1. Is RLE a desirable goal for biomedical research?

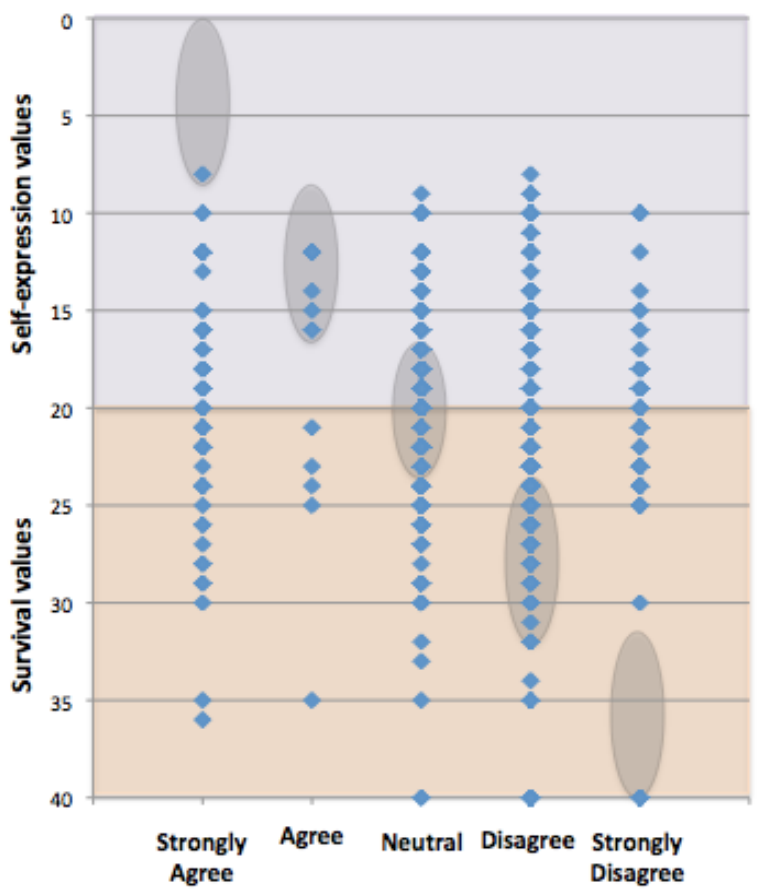


Figure 6. Question 4 decisions and Traditional vs. Secular-rational dimension. Q4. Would you avail of RLE if already in your advanced years?

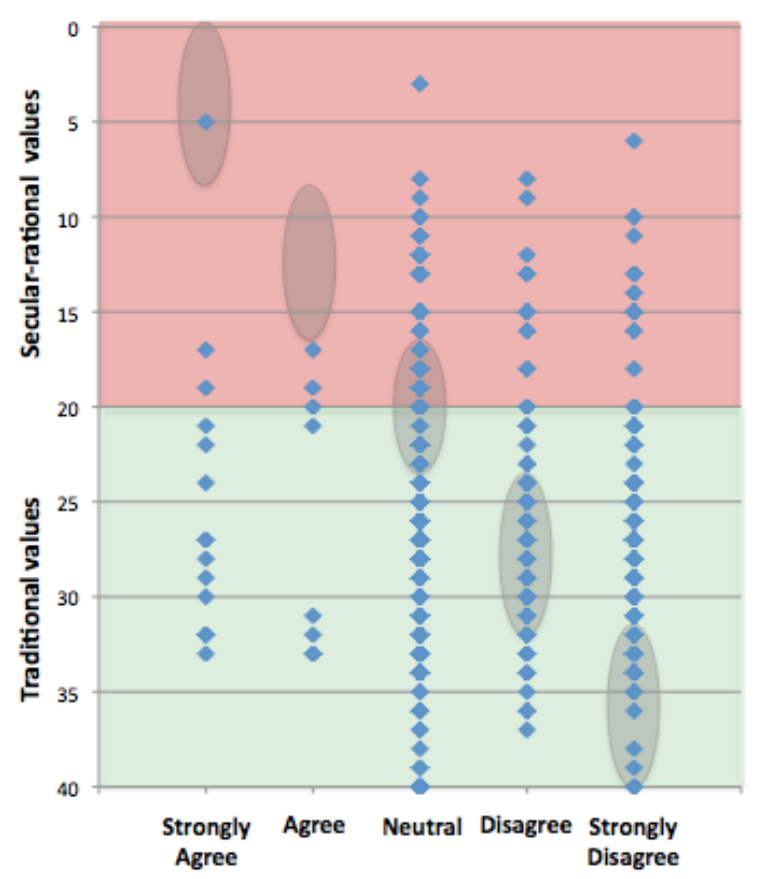

Figure 8. Question 5 decisions and Traditional vs. Secular-rational dimension. Q5. Is RLE compatible with your cultural values?

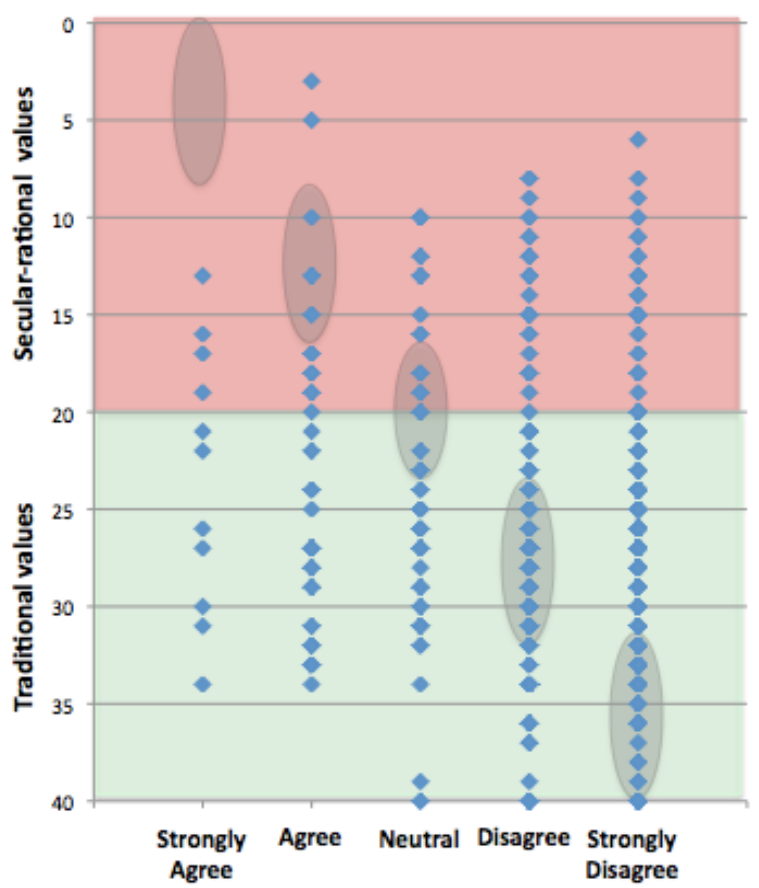

Figure ?. Question 4 decisions and Survival vs.Self-expression dimension. $\mathbf{0 4}$. Would you avail of RLE if already in your advanced years?

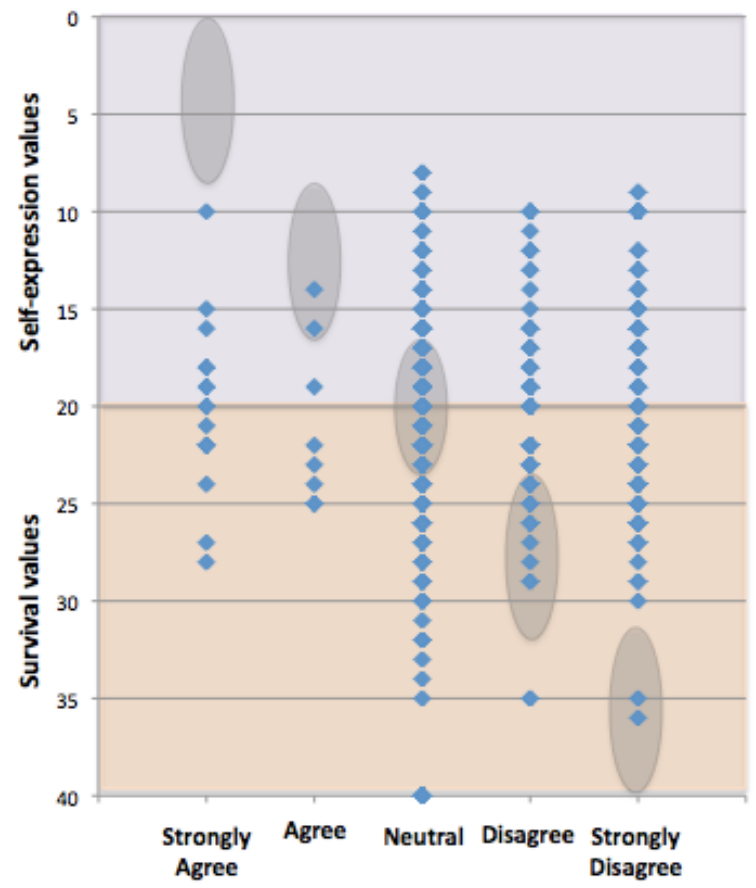

Figure 9. Question 5 decisions and Survival vs. Self-expression dimension. Q5. Is RLE compatible with your cultural values?

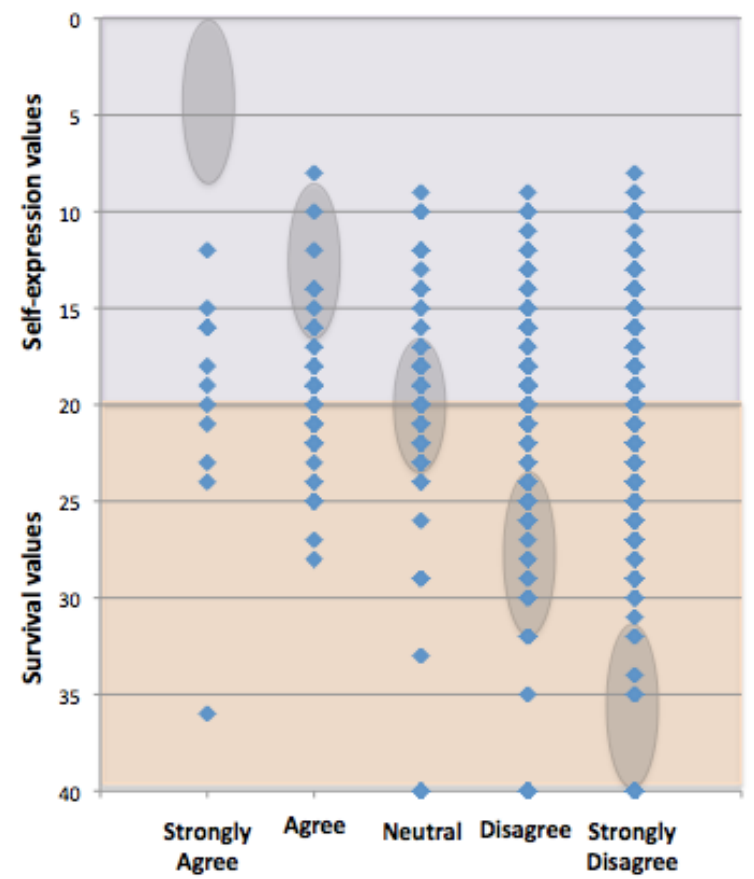


Figure 10. Question 3 decisions and Traditional vs. Secular-rational dimension. 03. Should we be concerned about effects on population growth?

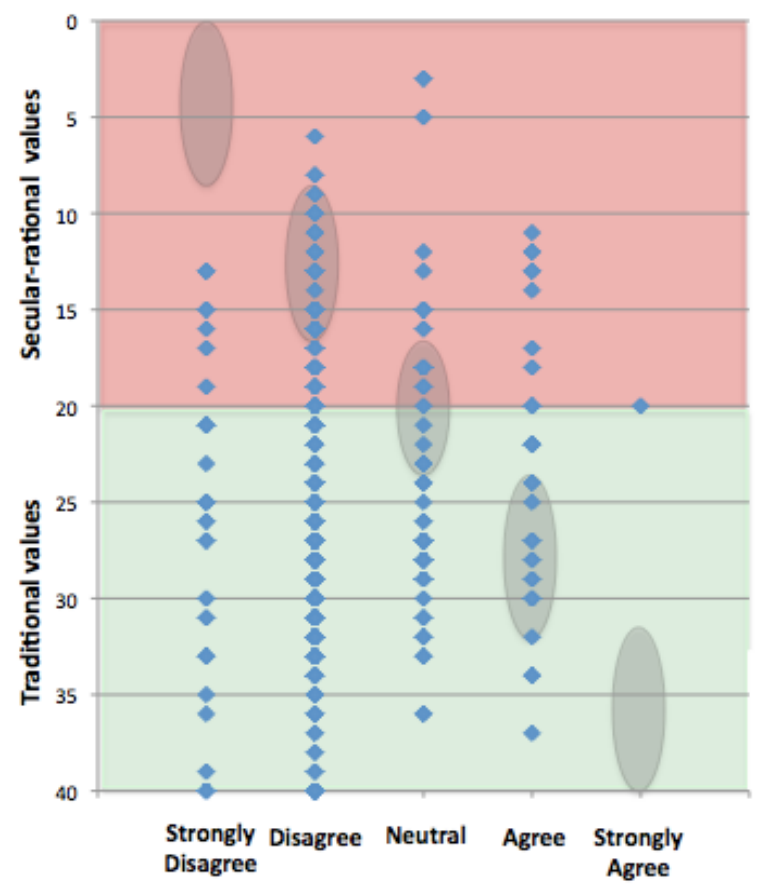

Figure 12. Question 2 decisions and Traditional vs. Secular-rational dimension. Q2. Which means to RLE is acceptable?

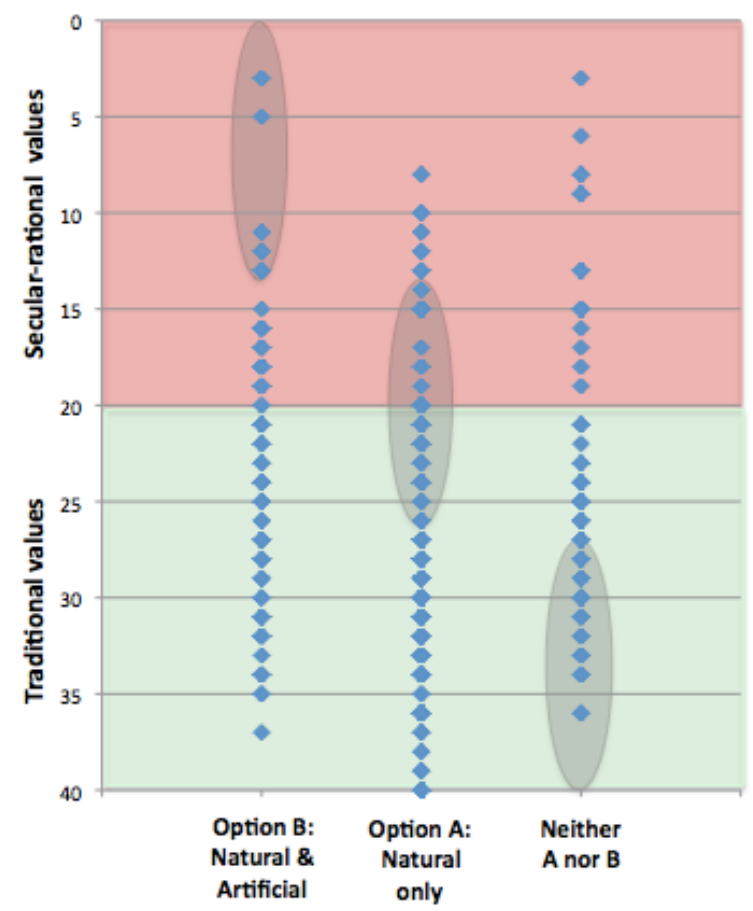

Figure 11. Question 3 decisions and Survival vs. Selfexpression dimension. Q3. Should we be concerned about effects on population growth?

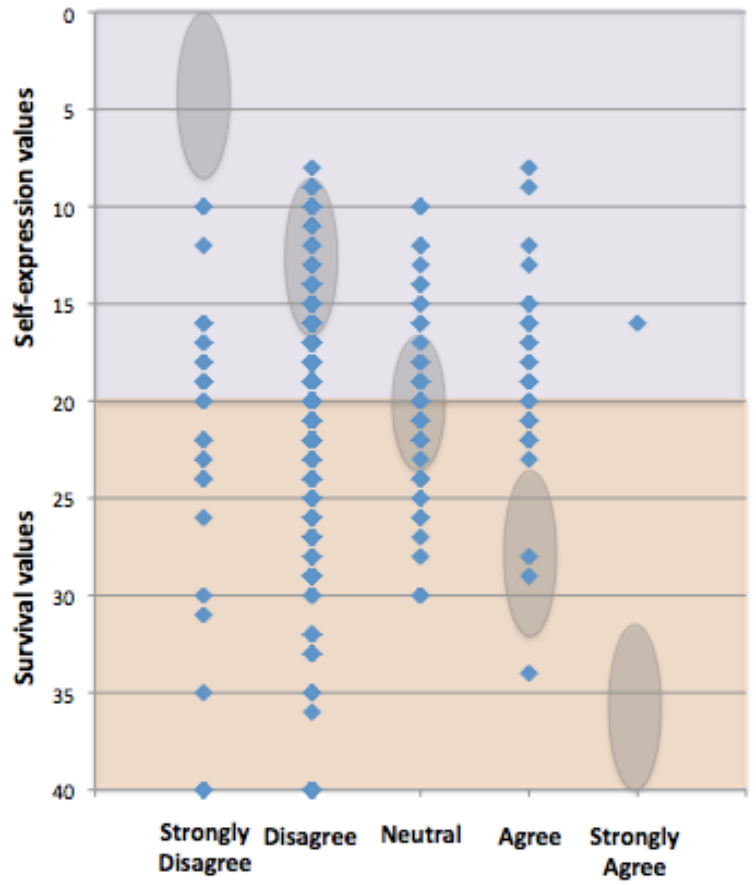

Figure 13. Question 2 decisions and Survival vs. Self-expression dimension. Q2. Which means to RLE is acceptable?

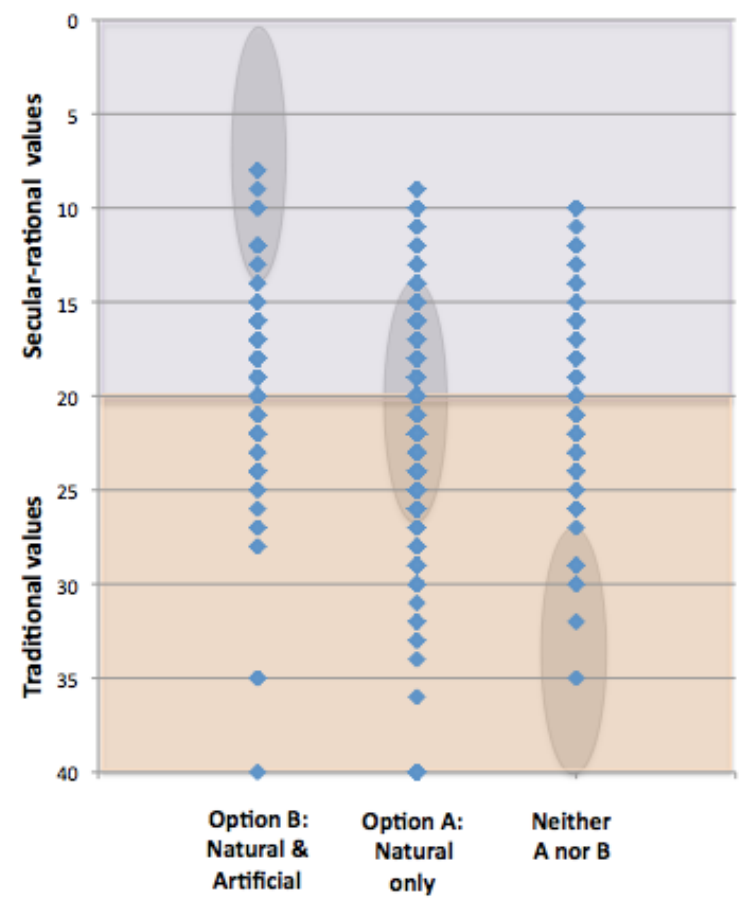




\section{Distribution of responses per cultural group}

\section{Q1. Biomedical research}

Chart 4 shows that those who preferred Traditional values were inclined to disagree (45\%) that RLE is a desirable goal for biomedical research and be neutral (39\%) about it. Only $10 \%$ strongly agreed.

Those who preferred Secular-rational values were inclined to be neutral (56\%), with $13 \%$ who disagreed and $26 \%$ who strongly disagreed. Only a few agreed (1\%) and strongly agreed $(4 \%)$.

In contrast, the majority of Survivalists (59\%) strongly disagreed that RLE is a desirable goal for biomedical research (20\% disagreed). A few were divided between being neutral $(10 \%)$ and agreeing (9\% plus $2 \%$ strongly agreeing).

Half of Self-expressionists (50\%) disagreed but many (37\%) were neutral about it. A few agreed (1\%) and strongly agreed (12\%).

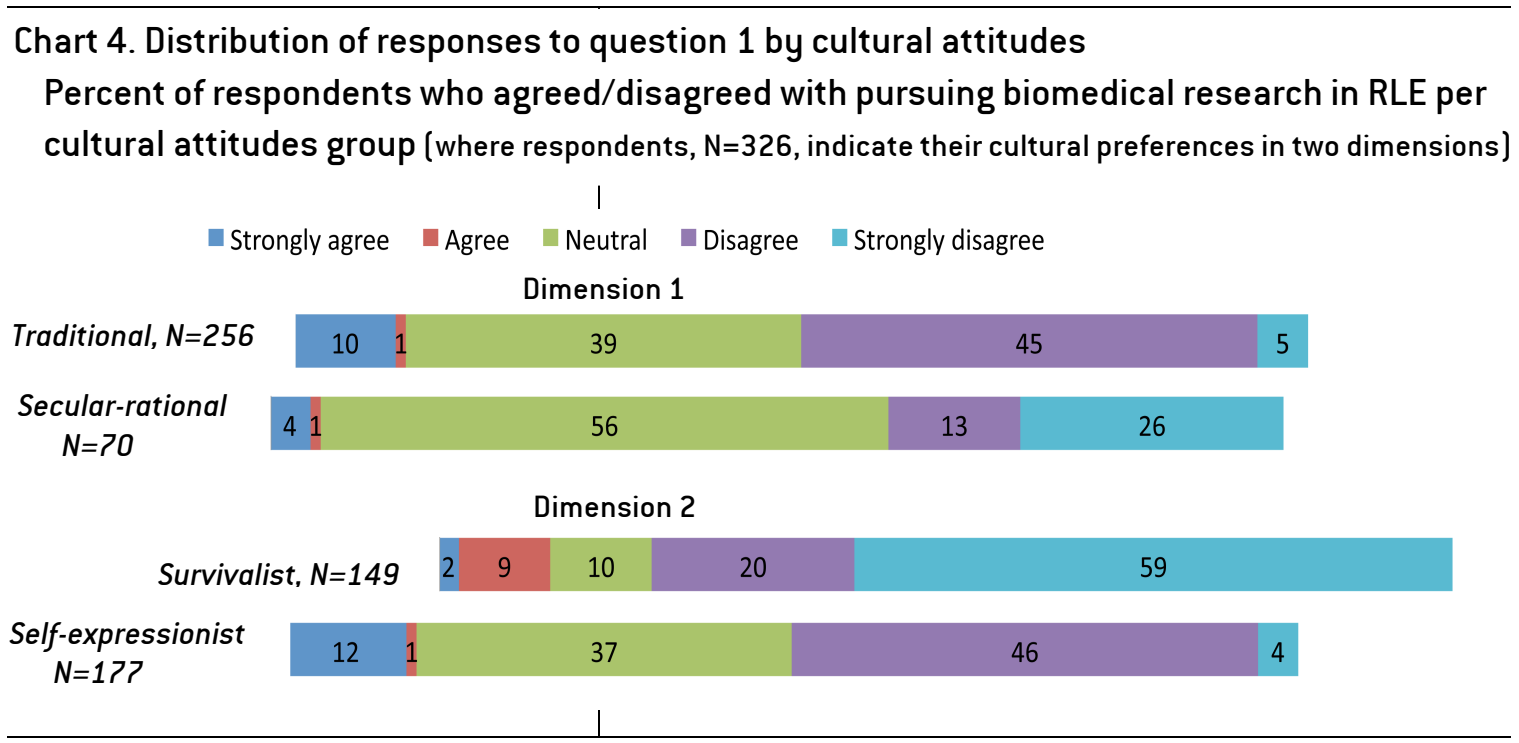

\section{Q4. Avail of RLE in old age}

The majority of participants across cultural attitudes were neutral as to whether they would avail themselves of RLE in their advanced years (see Chart 5). The most neutral were Secularrationalists (63\%) followed by Self-expressionists (58\%). Traditionalists and Survivalists were equally neutral (both 54\%) on the issue. There were also similarities between these groups in terms of being more inclined to disagree ( $21 \%$ to $29 \%$ strongly disagree) than agree (3\% to $4 \%$ strongly agree). These observations show that regardless of cultural attitudes, survey participants tended to have similar responses to the question of whether they would avail themselves of RLE technologies in their advanced years. It is interesting to note that when participants were presented with different reasons for being neutral, the top reason chosen was that they would not know how they would feel (262 votes) when they are in their advanced years (see Table 3 under the section Analysis of Reasons).

\section{Q5. Compatible with deeply held beliefs}

Many participants thought that RLE is not compatible with their deeply held beliefs. There were close similarities in how participants across cultural attitudes responded to the question whether RLE is compatible with their deeply held beliefs (see Chart 6). The majority of respondents from Traditionalists (64\%), Survivalists (61\%) and Self-expressionists (57\%) 
strongly disagreed. A similar, but small percentage of these three groups chose to be neutral $(8 \%, 8 \%$ and $12 \%$ respectively); agreed $(8 \%, 10 \%$ and $8 \%)$ and strongly agreed $(1 \%, 1 \%$ and $2 \%)$. Less than half but still significantly many (40\%) of Secular-rationalists strongly disagreed that RLE is compatible with their deeply held beliefs followed by those who disagreed $(25 \%)$ and were neutral (18\%) with $13 \%$ who agreed and $3 \%$ who strongly disagreed.

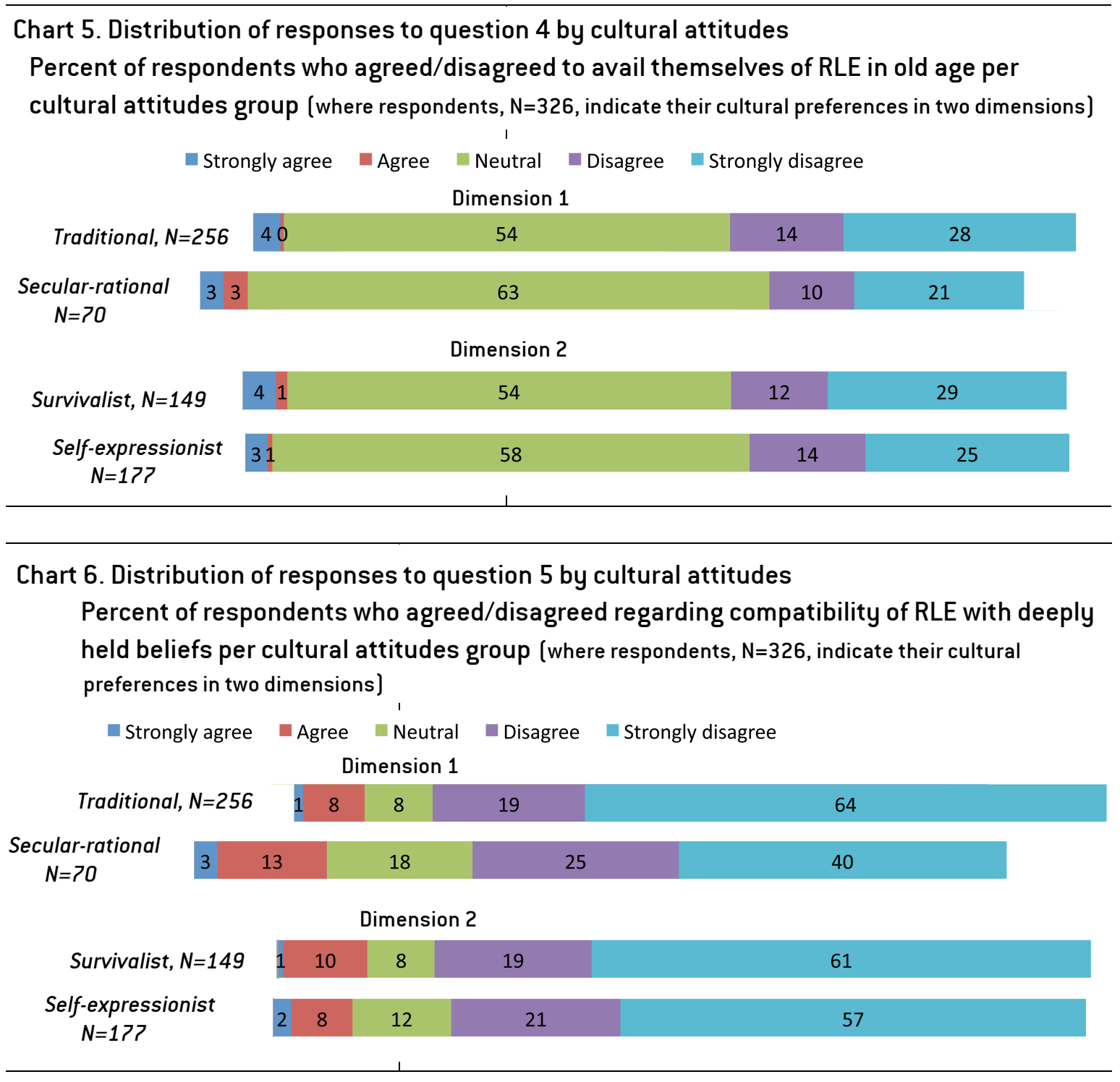

\section{Q3. Concern about effects on global population growth}

When asked whether we should be concerned about RLE's effects on global population growth, a significant majority of participants across all four dimensions of cultural attitudes responded that they agreed (see Chart 7): Traditionalists (82\%), Survivalist (81\%), Selfexpressionists (79\%) and Secular-rationalists (72\%), with a few who strongly disagreed (between 3\% to 4\%). A few others chose to be neutral (between 8\% to 14\%). Even fewer disagreed with the statement (between $5 \%$ to $10 \%$ ). Only a few strongly disagreed.

\section{Q2. Means to RLE}

The majority of Traditionalists (67\%) preferred only natural means for facilitating RLE (see Chart 8 ). Some (19\%) were open to using artificial means in addition to natural means while 
others (14\%) preferred neither.

Secular-rationalists were divided between those who would allow natural means only (42\%) and those who would accept artificial means in addition to natural means (43\%). A few (15\%) preferred neither option, perhaps, because they reject RLE.

A majority of Survivalists (70\%) preferred only natural means to achieve RLE. However, a few $(18 \%)$ were open to artificial means in addition to natural means. The rest $(12 \%)$ preferred neither option.

Similarly, the majority of Self-expressionists (54\%) also preferred natural means only, but many (30\%) were open to artificial means in addition to natural means. The remainder (16\%) preferred neither option.

There seems to be some broad similarities in patterns in the way each cultural group responded to the questions (see Charts $9-12$ ).

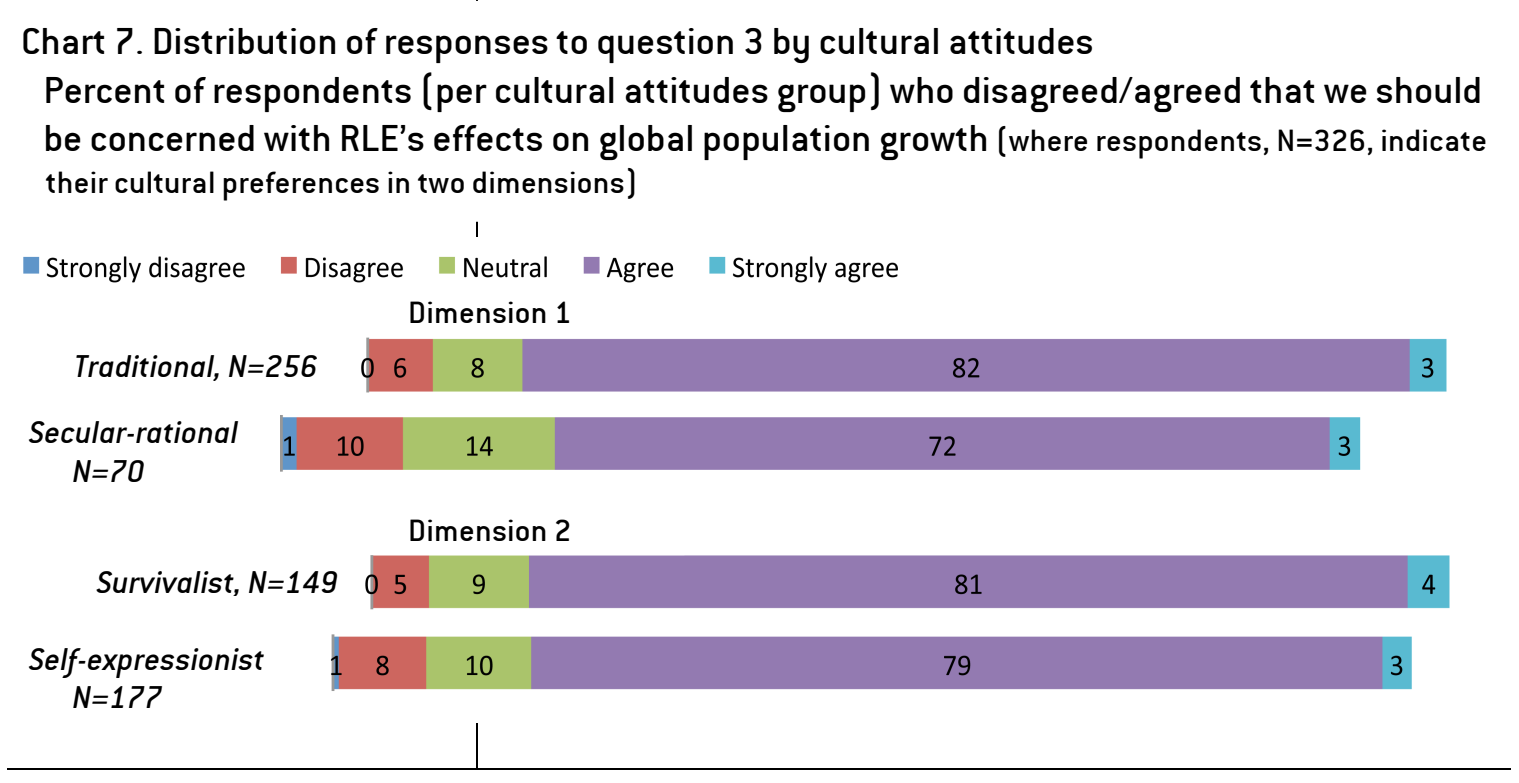

Chart 8. Distribution of responses to question 2 by cultural attitudes

Percent of respondents (per cultural attitudes group) who preferred a particular approach

to $\mathrm{RLE}$ (where respondents, $\mathrm{N}=326$, indicate their cultural preferences in two dimensions)

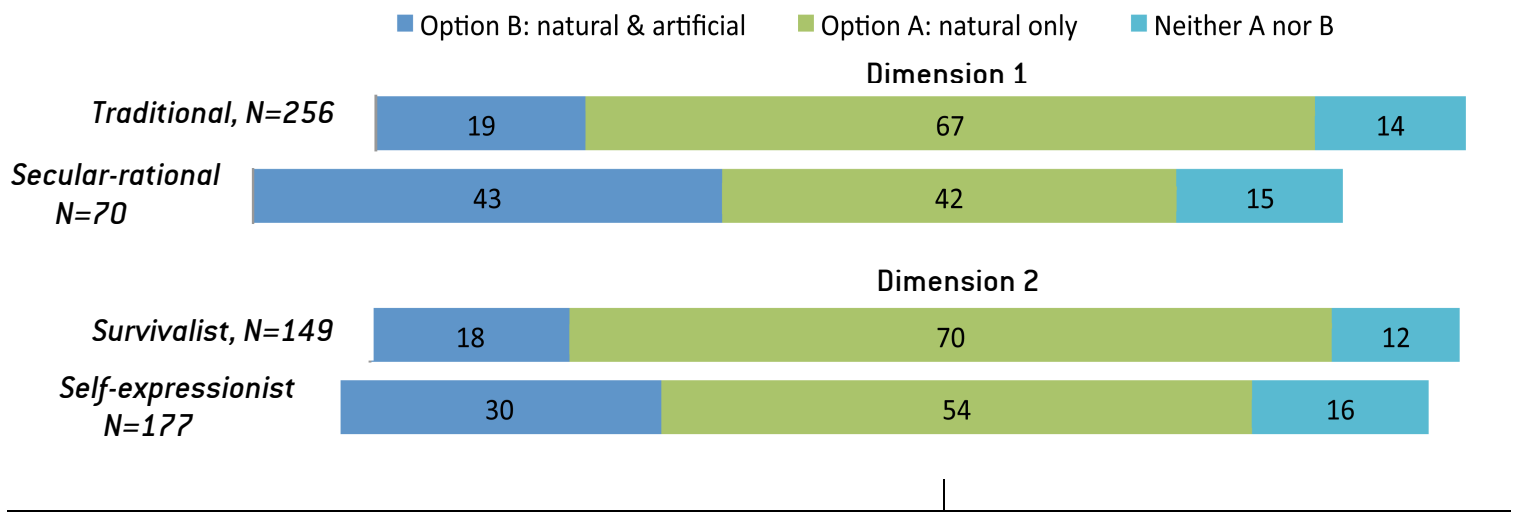




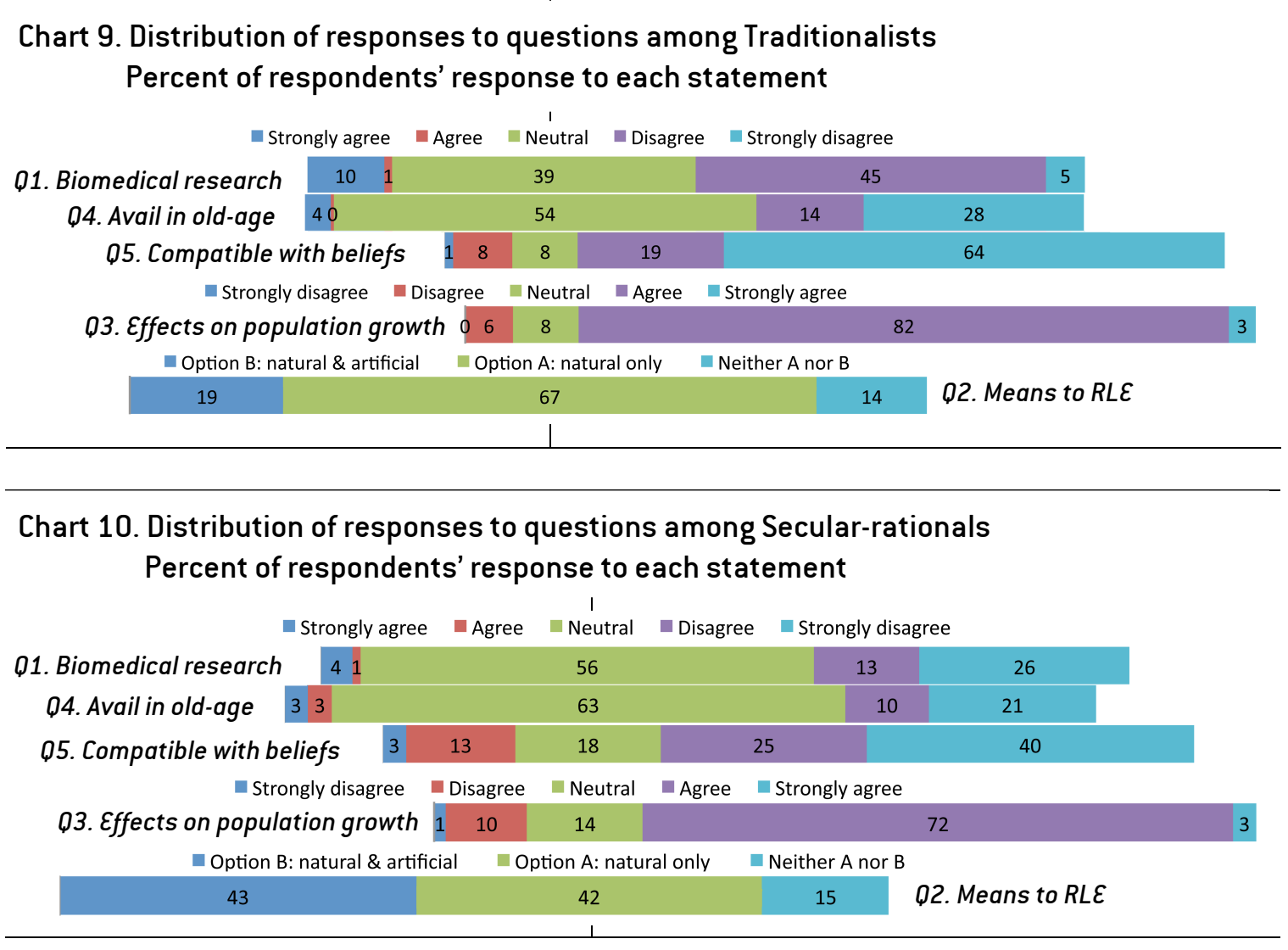

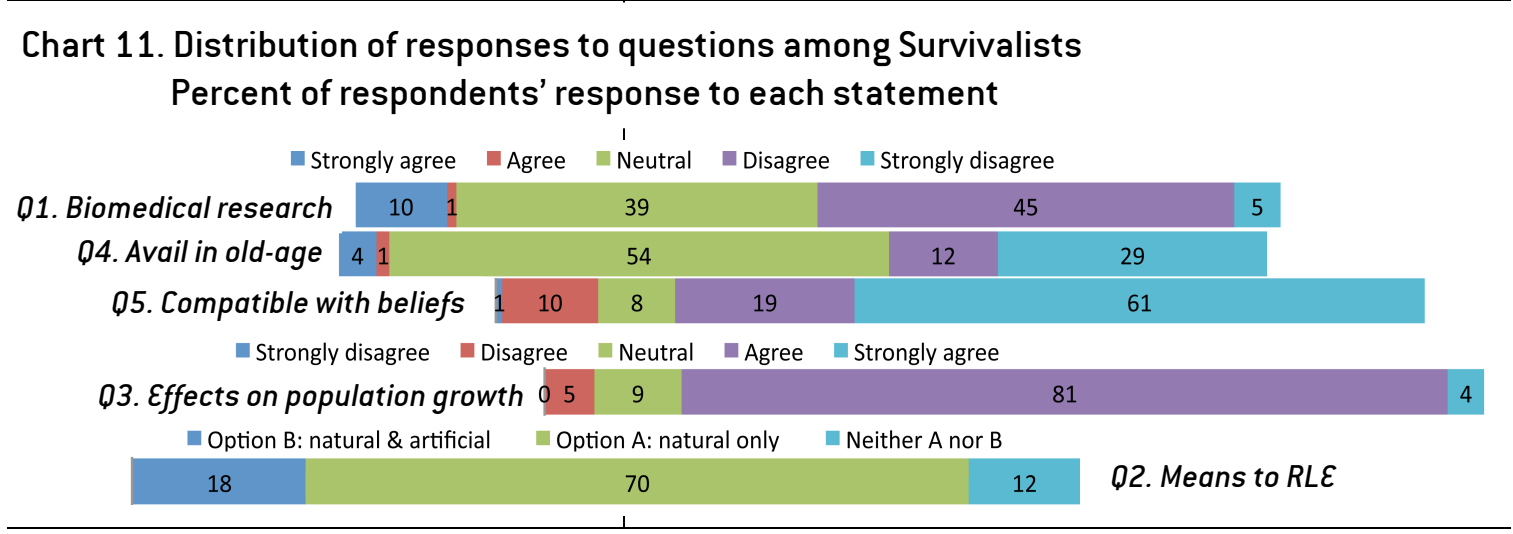

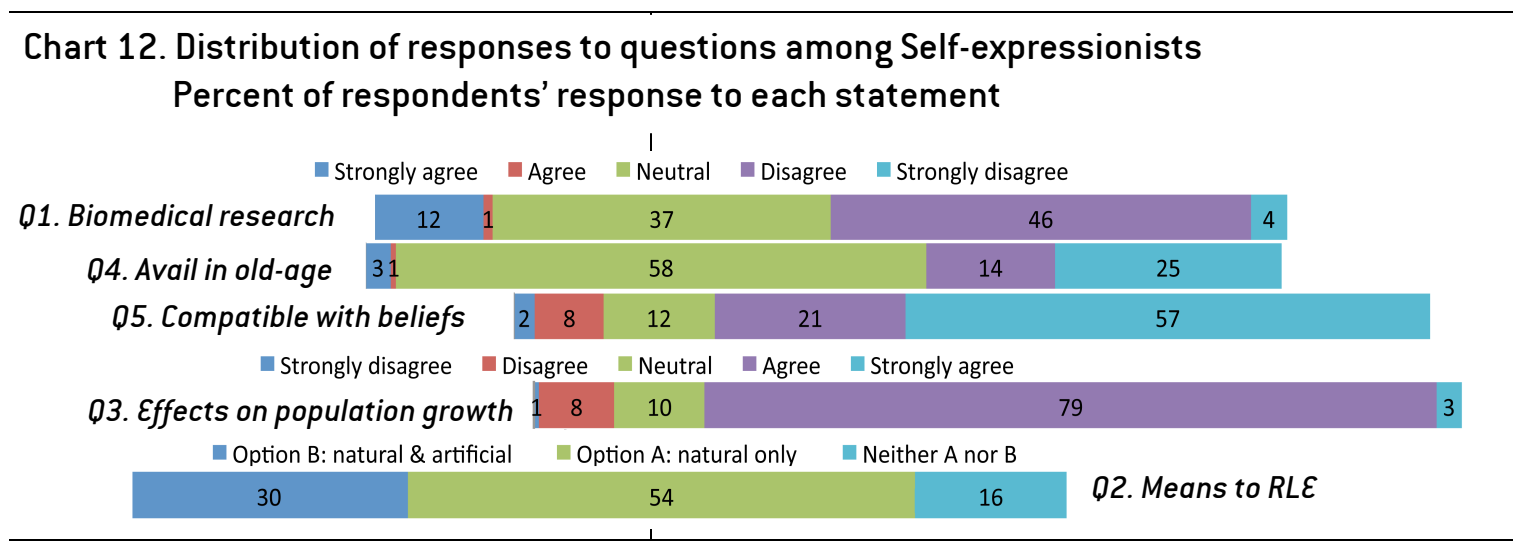




\section{Analysis of Reasons}

We selected the top two reasons per decision in Tables 3 - 7 to explore the reasoning behind the mixed responses observed in the aggregated and group-based decisions. The reasons that were included in the tables were quoted verbatim from the online survey. We chose to present these as they were posted by participants without correcting for typographical or grammatical errors to present the actual words in their original form as written by participants. Adhering to a naturalized presentation of the actual words written by participants allowed us to capture a wealth of information and add rich detail to our analysis of these texts as dialogue between participants. ${ }^{10}$ Favoring the natural as opposed to the idealized presentation of these reasons also made our analysis more transparent because it shows what the participants actually wrote.

The top reasons provide some details as to what participants think about ethical controversies surrounding RLE. Perhaps the dominance of disapproval of RLE across cultural groups corresponds to the kind of response that the disruption of well-established moral routines elicits (Swierstra \& Rip, 2007), especially among those who may have undergone formal training or education that might have influenced moral routines related to existing technologies. As observed in the 2013 Pew Research study (Funk et al., 2013), those who have more formal education are slightly less inclined to say that RLE is a positive development for society.

\section{'No' to RLE research because of overpopulation risk}

Question 1 asks about the desirability of RLE biomedical research (Table 3). The top reason for disagreeing with allowing the pursuit of biomedical research on RLE (Q1) concerns the risk of overpopulation (197 votes). The same concern was mentioned in the top two reasons for strongly disagreeing. The top reason for being neutral was because of worries about extending life without quality (103 votes). The top reason for strongly agreeing was based on optimism that if technologies can be developed to extend life, then technologies can also be developed to solve problems associated with overpopulation (69 votes).

\section{Don't know if I would avail myself of RLE when I am old}

Question 4 asks whether participants would avail themselves of RLE in their old age (see Table 4). Most respondents (262 votes) who selected neutral chose the reason "Do not know how I will feel when old." Could the fact that most respondents were young university students be related to this response? We do not have survey participants in their advanced years so we do not know if age is correlated to this response. ${ }^{11}$ The next reason chosen by most participants (101 votes) was strongly agreeing because aging is natural and RLE is selfish followed by disagreeing ( 69 votes) because of the risk of life extension without quality of life. Those who chose reasons to agree and strongly agree were optimistic about the greater opportunities RLE could offer.

\section{To age is natural: accept death!}

That aging is natural and death is acceptable was chosen by many ( 215 votes) as the reason for strongly disagreeing that RLE is compatible with deeply held beliefs (see Table 5). This was followed by responses that highlighted the risk of societal stagnation when lives are radically extended (124 votes). A few who were neutral chose the reason that death is acceptable. The top reasons cited for agreeing and disagreeing expressed optimism about opportunities and the value of freedom to choose. 
Table 3. Top two reasons for each decision in Question 1

\begin{tabular}{|c|c|c|c|c|c|}
\hline Decision & Vote & Rank & Reason & Code $[s]$ & Cls \\
\hline \multirow[t]{2}{*}{$\begin{array}{l}\text { Strongly } \\
\text { Disagree }\end{array}$} & 14 & 1 & $\begin{array}{l}\text { RLE needs a great fund... Why not } \\
\text { help the ones in need ... you're not } \\
\text { sure if it will be successful or not!? } \\
\text {...if RLE will be successful, then the } \\
\text { over-populated world will be more } \\
\text { populated...be a big depletion of } \\
\text { resources for sure because there will } \\
\text { be a big competition for it. Third, the } \\
\text { bad habits of people will continue like } \\
\text { smoking, taking prohibited drugs, } \\
\text { and many more. This is because } \\
\text {...there's... RLE.. }\end{array}$ & $\begin{array}{l}\text { a. RLE is resource } \\
\text { demanding } \\
\text { b. Meeting needs } \\
\text { should be prioritized } \\
\text { c. RLE success } \\
\text { uncertain } \\
\text { d. overpopulation risk } \\
\text { e. Depletion of } \\
\text { resources } \\
\text { f. Risk of careless living } \\
\text { due to reliance on } \\
\text { RLE }\end{array}$ & 112 \\
\hline & 13 & 2 & $\begin{array}{l}\text {...Extending the life of a person would } \\
\text { add to the population and we cannot } \\
\text { afford to have huge population now } \\
\text { for we can't sustain it's needs. }\end{array}$ & $\begin{array}{l}\text { a. overpopulation risk } \\
\text { b. Depletion of } \\
\text { resources }\end{array}$ & 20 \\
\hline & 197 & 1 & $\begin{array}{l}\text { The population on earth is increasing } \\
\text { due to the fact that peoples live } \\
\text { longer... The population on earth } \\
\text { should follow the degree of increase } \\
\text { in total technology development. }\end{array}$ & $\begin{array}{l}\text { a. overpopulation risk } \\
\text { b. Develop technology } \\
\text { first before increasing } \\
\text { population }\end{array}$ & 31 \\
\hline Disagree & 30 & 2 & $\begin{array}{l}\text { People wouldn't give importance } \\
\text { much to their life because...there is } \\
\text { RLE... They won't live their life to the } \\
\text { fullest... }\end{array}$ & $\begin{array}{l}\text { Risk of careless living } \\
\text { due to reliance on RLE }\end{array}$ & 57 \\
\hline \multirow[b]{2}{*}{ Neutral } & 103 & 1 & $\begin{array}{l}\text {...trying to extend life without } \\
\text { attention on improving the quality of } \\
\text { life... Living life is about the person's } \\
\text { ability not their age. }\end{array}$ & $\begin{array}{l}\text { Risk of life extension } \\
\text { without quality }\end{array}$ & 33 \\
\hline & 60 & 2 & $\begin{array}{l}\text { it is more like quality over } \\
\text { quantity...A long life would be } \\
\text { meaningless if there is an absence of } \\
\text { value and love in that life and in the } \\
\text { person living it... we...can never } \\
\text { control or choose our death; but only } \\
\text { choose how we will live. }\end{array}$ & $\begin{array}{l}\text { a. Risk of life extension } \\
\text { without quality } \\
\text { b. Death unavoidable }\end{array}$ & 30 \\
\hline \multirow[b]{2}{*}{ Agree } & 6 & 1 & $\begin{array}{l}\text {...it may result in valuable } \\
\text { technology across a range of fields, } \\
\text { not necessarily just to make the } \\
\text { technology available and extend } \\
\text { normal people's lives by X years. }\end{array}$ & $\begin{array}{l}\text { RLE may result to } \\
\text { valuable technology }\end{array}$ & 33 \\
\hline & 2 & 2 & $\begin{array}{l}\text {...living healthy is not dangerous at } \\
\text { all...It will also teach the people } \\
\text { discipline... which can answer the } \\
\text { issue others are saying-hunger and } \\
\text { overpopulation's negative side effects. } \\
{\left[{ }^{*} \text { responds to overpop...] }\right.}\end{array}$ & $\begin{array}{l}\text { a. RLE as healthy living } \\
\text { b. Healthy living teach } \\
\text { discipline } \\
\text { c. Discipline will solve } \\
\text { hunger and } \\
\text { overpopulation }\end{array}$ & 74 \\
\hline \multirow{2}{*}{$\begin{array}{l}\text { Strongly } \\
\text { Agree }\end{array}$} & 69 & 1 & $\begin{array}{l}\text {...one of the many ways that we can } \\
\text { use technology...to create solutions } \\
\text { for the overpopulation problem }\end{array}$ & $\begin{array}{l}\text { Technology may solve } \\
\text { overpopulation }\end{array}$ & 43 \\
\hline & 16 & 2 & $\begin{array}{l}\text { RLE is not just a matter of quantity, } \\
\text { but of quality as well. }\end{array}$ & $\begin{array}{l}\text { RLE can increase } \\
\text { quality of life }\end{array}$ & 43 \\
\hline
\end{tabular}


Table 4. Top two reasons for each decision in Question 4

\begin{tabular}{|c|c|c|c|c|c|}
\hline Decision & Vote & Rank & Reason & Code[s] & Cls \\
\hline \multirow{2}{*}{$\begin{array}{l}\text { Strongly } \\
\text { Disagree }\end{array}$} & 101 & 1 & $\begin{array}{l}\text { when my natural life has run its } \\
\text { course, I do not wish to... selfishly, } \\
\text { extend it. }\end{array}$ & $\begin{array}{l}\text { a. Aging is natural } \\
\text { b. RLE is selfish }\end{array}$ & 3 \\
\hline & 10 & 2 & $\begin{array}{l}\text { If God wants me to live longer, He } \\
\text { will heal me- no need for anything } \\
\text { artificial. And, I want to meet my } \\
\text { Savior. }\end{array}$ & $\begin{array}{l}\text { a. Living longer is not } \\
\text { up to me } \\
\text { b. Death is acceptable }\end{array}$ & 74 \\
\hline \multirow[b]{2}{*}{ Disagree } & 69 & 1 & $\begin{array}{l}\text { I would not wish to extend my life if } \\
\text { it did not include improving the } \\
\text { quality of my life. }\end{array}$ & $\begin{array}{l}\text { Risk of life extension } \\
\text { without quality }\end{array}$ & 33 \\
\hline & 6 & 2 & $\begin{array}{l}\text { Life is a precious gift. Death is a } \\
\text { limitation which is set in order for } \\
\text { men to live their lives to the fullest, } \\
\text { to value it, and to not take it for } \\
\text { granted. }\end{array}$ & $\begin{array}{l}\text { a. Acceptance of death } \\
\text { b. Valuing life }\end{array}$ & $\begin{array}{r}11 \\
1\end{array}$ \\
\hline \multirow[t]{2}{*}{ Neutral } & 262 & 1 & $\begin{array}{l}\text { I am not in my advanced years, and } \\
\text { have no notion about how I may or } \\
\text { may not feel when I am }\end{array}$ & $\begin{array}{l}\text { Do not know how I } \\
\text { feel when old }\end{array}$ & 33 \\
\hline & 29 & 2 & $\begin{array}{l}\text {...I don't know what my life would } \\
\text { be being an old man/lady.. }\end{array}$ & $\begin{array}{l}\text { Do not know how I } \\
\text { feel when old }\end{array}$ & 43 \\
\hline Agree & 6 & 1 & $\begin{array}{l}\text {...the thought of passing on such an } \\
\text { opportunity seems so idiotic. There } \\
\text { are a lot of things that you can do } \\
\text { here on earth that you cannot with } \\
\text { only } 80 \text { years at hand... }\end{array}$ & $\begin{array}{l}\text { RLE provides more } \\
\text { opportunities }\end{array}$ & 75 \\
\hline \multirow{2}{*}{$\begin{array}{l}\text { Strongly } \\
\text { Agree }\end{array}$} & 21 & 1 & $\begin{array}{l}\text {...It would give me more } \\
\text { opportunities to be with the ones I } \\
\text { love and care about. maybe, to do } \\
\text { something else... }\end{array}$ & $\begin{array}{l}\text { RLE provides more } \\
\text { opportunities }\end{array}$ & 33 \\
\hline & 1 & 2 & $\begin{array}{l}\text { one lifetime is not enough to do all } \\
\text { things in the world. We are human, } \\
\text { we always crave for something. In } \\
\text { the future, technologies will evolve } \\
\text { very fast and new and new } \\
\text { discoveries will arise, one lifetime is } \\
\text { not enough to witness this, it is a } \\
\text { waste not to chose to see the future } \\
\text { that we could only imagine for now }\end{array}$ & $\begin{array}{l}\text { RLE provides more } \\
\text { opportunities }\end{array}$ & 74 \\
\hline
\end{tabular}

\section{We should be concerned about overpopulation}

Question 3 explicitly asked whether we should be concerned with overpopulation (see Table 6). Many (313 votes) said the reason they agreed was because we should be concerned that sustainable policy be prioritized and quality of life improved first. This was followed by reasons that expressed worry about the risk of further worsening the problem of unemployment ( 97 votes). Those who chose reasons to be neutral were unsure whether the benefits could outweigh the risks. Some participants who chose reasons to disagree seemed to disagree with RLE rather than with the statement about being concerned with the effect of RLE on population growth. Those reasons (not shown in the tables) are about the risk of boredom, the risk of increasing the number of retirees due to RLE, and preference of death over RLE. 
Table 5. Top two reasons for each decision in Question 5

\begin{tabular}{|c|c|c|c|c|c|}
\hline Decision & Vote & Rank & Reason & Code[s] & Cls \\
\hline \multirow[b]{2}{*}{$\begin{array}{l}\text { Strongly } \\
\text { Disagree }\end{array}$} & 215 & 1 & $\begin{array}{l}\text { People grow old, this has been a } \\
\text { natural law for as long as human kind } \\
\text { has existed... }\end{array}$ & $\begin{array}{l}\text { a. Aging is natural } \\
\text { b. Death is acceptable }\end{array}$ & 31 \\
\hline & 36 & 2 & $\begin{array}{l}\text {... unfair to the vast majority of the } \\
\text { current population who are suffering } \\
\text { because of the unsustainable way in } \\
\text { which we have treated the earth so } \\
\text { far, but also to future generations } \\
\text { who must be denied life because we } \\
\text { want to be here longer (if we are to } \\
\text { ensure a sustainable population size } \\
\text { in the futire)... }\end{array}$ & $\begin{array}{l}\text { RLE is unfair to present } \\
\text { and future generation }\end{array}$ & 33 \\
\hline \multirow[b]{2}{*}{ Disagree } & 124 & 1 & $\begin{array}{l}\text { eternal life seems like it would lead to } \\
\text { a stagnant society - when everyone } \\
\text { lives forever, new ideas get drowned } \\
\text { in an ocean of preconception. Death, } \\
\text { if nothing else, ensures motion. }\end{array}$ & $\begin{array}{l}\text { Risk of societal } \\
\text { stagnation }\end{array}$ & 31 \\
\hline & 6 & 2 & $\begin{array}{l}\text {...society is a mix of old and new } \\
\text { values and is a balance between the } \\
\text { two. If I live longer that I am prone to } \\
\text { make decisions for society based on } \\
\text { old values and hampering new values } \\
\text { from existing... }\end{array}$ & $\begin{array}{l}\text { Risk of societal } \\
\text { stagnation }\end{array}$ & 33 \\
\hline \multirow[b]{2}{*}{ Neutral } & 33 & 1 & $\begin{array}{l}\text { RLE doesn't make death impossible. } \\
\text { It just postpones it. So, even with the } \\
\text { use of RLE accepting and coping with } \\
\text { death will never disappear from our } \\
\text { culture. }\end{array}$ & $\begin{array}{l}\text { a. RLE postpones death } \\
\text { b. Death is acceptable }\end{array}$ & 74 \\
\hline & 8 & 2 & $\begin{array}{l}\text { death is a sweet release for me if I } \\
\text { were suffering so much for so long. } \\
\text { Otherwise, it's perfectly reasonable } \\
\text { that I want to extend my life if I } \\
\text { would be able to do more being alive } \\
\text { than dead for that particular period } \\
\text { in my lifetime... }\end{array}$ & $\begin{array}{l}\text { a. Death is acceptable if } \\
\text { suffering } \\
\text { b. RLE provides more } \\
\text { opportunities }\end{array}$ & 74 \\
\hline \multirow[b]{2}{*}{ Agree } & 18 & 1 & $\begin{array}{l}\text {... we should study and Explorer all } \\
\text { options available. }\end{array}$ & $\begin{array}{l}\text { RLE should be studied } \\
\text { and explored }\end{array}$ & 33 \\
\hline & 15 & 2 & $\begin{array}{l}\text {...While I do not wish to be } \\
\text { physically immortal, being given the } \\
\text { choice of extending my time in this } \\
\text { world in order to appreciate and } \\
\text { understand life better is always a plus } \\
\text { for me. }\end{array}$ & $\begin{array}{l}\text { RLE provides more } \\
\text { opportunities }\end{array}$ & 43 \\
\hline \multirow{2}{*}{$\begin{array}{l}\text { Strongly } \\
\text { Agree }\end{array}$} & 8 & 1 & $\begin{array}{l}\text { life is all about choices ... extending } \\
\text { the lives of those who wishes to do so } \\
\text { is not entirely equivalent to denying } \\
\text { life to the future generations. }\end{array}$ & $\begin{array}{l}\text { RLE does not deny life } \\
\text { to future persons }\end{array}$ & 74 \\
\hline & 1 & 2 & $\begin{array}{l}\text { I believe that we are born to live the } \\
\text { life that we choose, if I choose to live } \\
\text { longer that is my prerogative, I } \\
\text { believe that we should always have a } \\
\text { choice. }\end{array}$ & $\begin{array}{l}\text { RLE should be allowed } \\
\text { if chosen }\end{array}$ & 74 \\
\hline
\end{tabular}


Table 6. Top two reasons for each decision in Question 3

\begin{tabular}{|c|c|c|c|c|c|}
\hline Decision & Vote & Rank & Reason & Code $[s]$ & Cls \\
\hline $\begin{array}{l}\text { Strongly } \\
\text { Disagree }\end{array}$ & 1 & 1 & $\begin{array}{l}\text { overpopulation is not a problem if } \\
\text { they can work harmoniously. }\end{array}$ & $\begin{array}{l}\text { Overpopulation not a } \\
\text { problem }\end{array}$ & 74 \\
\hline \multirow[t]{2}{*}{ Neutral } & 39 & 1 & $\begin{array}{l}\text { If there are little recourses due to } \\
\text { overpopulation than persons can not } \\
\text { benefit society - however if a person } \\
\text { lives longer they can in return } \\
\text { provide more benefit to society with } \\
\text { the recourses that where already } \\
\text { invested. What is true that in order to } \\
\text { grow as a society we need a constant } \\
\text { recycle of persons... }\end{array}$ & $\begin{array}{l}\text { a. Overpopulation risk } \\
\text { b. longer life benefits } \\
\text { society } \\
\text { c. constant replacement } \\
\text { of people good for } \\
\text { society }\end{array}$ & 33 \\
\hline & 21 & 2 & $\begin{array}{l}\text { We do not know enough about } \\
\text { overpopulation. With the technology } \\
\text { level RLE requires, technologies to } \\
\text { address possible problems } \\
\text { concerning overpopulation may be } \\
\text { available at the time it would be } \\
\text { necessary in a RLE perspective. }\end{array}$ & $\begin{array}{l}\text { a. Overpopulation risk } \\
\text { b. RLE requires } \\
\text { technologies to solve } \\
\text { overpopulation }\end{array}$ & 33 \\
\hline \multirow[t]{2}{*}{ Agree } & 313 & 1 & $\begin{array}{l}\text {... we must first worry about } \\
\text { developing a sustainable and } \\
\text { compassionate policy to raise the } \\
\text { quality of life for all persons before } \\
\text { we start worrying about extending } \\
\text { life beyond what is currently } \\
\text { unsustainable. }\end{array}$ & $\begin{array}{l}\text { Sustainable policy } \\
\text { priority over RLE }\end{array}$ & 33 \\
\hline & 97 & 2 & $\begin{array}{l}\text { it seems unlikely that there would be } \\
\text { enough jobs for everyone. By not } \\
\text { having any retirement, the positions } \\
\text { in various companies would be } \\
\text { extremely rigid - you can not easily } \\
\text { fire someone who has held the same } \\
\text { job for } 40 \text { years, let alone } 100 \text {. The } \\
\text { prospects for new employees would } \\
\text { thus be low, and we could see a class } \\
\text { division arising between old and } \\
\text { young. }\end{array}$ & $\begin{array}{l}\text { a. Jobs will become } \\
\text { scarce } \\
\text { b. Hiring requirements } \\
\text { will become rigid } \\
\text { c. Risk of conflict } \\
\text { between young and } \\
\text { old workers }\end{array}$ & 31 \\
\hline \multirow[b]{2}{*}{$\begin{array}{l}\text { Strongly } \\
\text { Agree }\end{array}$} & 6 & 1 & $\begin{array}{l}\text {... not aging at all means that there's } \\
\text { no purpose on having a child thus no } \\
\text { evolution will happen. }\end{array}$ & $\begin{array}{l}\text { Risk of societal } \\
\text { stagnation }\end{array}$ & 74 \\
\hline & 2 & 2 & $\begin{array}{l}\text {..If the average life span of the } \\
\text { individual is going to rise by RLE, } \\
\text { then feeding, curing and housing will } \\
\text { be more complex issues than ever } \\
\text { before. }\end{array}$ & $\begin{array}{l}\text { Meeting basic needs } \\
\text { will become more } \\
\text { difficult }\end{array}$ & 198 \\
\hline
\end{tabular}

\section{OK if RLE is done in a natural way?}

Question 2 tested whether participants were willing to consider natural means to achieve RLE (Table 7). Many chose the reason (230 votes) that expressed willingness to support RLE if the methods to be used were exclusively natural. This was followed by the reason that supported combining natural with artificial means if proven safe and effective (76 votes). Some insisted that RLE couldn't be natural (36 votes). A significant number of participants (65 votes) said 
the reason for rejecting RLE whether by natural or artificial means was because improving the environment should be the priority.

Table ?. Top two reasons for each decision in Question 2

\begin{tabular}{|c|c|c|c|c|c|}
\hline Decision & Vote & Rank & Reason & Code[s] & Cls \\
\hline \multirow{2}{*}{$\begin{array}{l}\text { I prefer } \\
\text { neither A } \\
\text { nor B }\end{array}$} & 65 & 1 & $\begin{array}{l}\text {...If we want to extend life then we } \\
\text { need to extend it first and foremost } \\
\text { by improving our enviroment (what } \\
\text { is the point of living longer in an } \\
\text { unhealthy enviroment?). }\end{array}$ & $\begin{array}{l}\text { Improving the } \\
\text { environment is priority }\end{array}$ & 33 \\
\hline & 14 & 2 & $\begin{array}{l}\text { i don't think RLE is a desirable } \\
\text { approach, therefore of course i can } \\
\text { not prefer a method heading towards } \\
\text { it. }\end{array}$ & RLE is not desirable & 31 \\
\hline \multirow{2}{*}{$\begin{array}{l}\text { Option A: } \\
\text { natural } \\
\text { only }\end{array}$} & 230 & 1 & $\begin{array}{l}\text { This is the natural way of dealing } \\
\text { with aging. }\end{array}$ & This is the natural way & 31 \\
\hline & 23 & 2 & $\begin{array}{l}\text { the long-term side effects of option B } \\
\text { will take a long time to discover, } \\
\text { especially because large companies } \\
\text { have an interest in them not to be } \\
\text { discovered. }\end{array}$ & $\begin{array}{l}\text { Artificial means will } \\
\text { have side effects in the } \\
\text { long-term }\end{array}$ & 33 \\
\hline \multirow[t]{2}{*}{$\begin{array}{l}\text { Option B: } \\
\text { natural } \\
\text { and } \\
\text { artificial }\end{array}$} & 76 & 1 & $\begin{array}{l}\text { with the help of natural means and } \\
\text { the additional aid of } \\
\text { pharmaceuticals, genetic } \\
\text { engineering, and nanotechnology, it } \\
\text { is not beyond the realm of possibility } \\
\text { for us to be capable of altering } \\
\text { ourselves to someday become } \\
\text { immune to diseases... This is all in } \\
\text { the context of a situation wherein } \\
\text { both natural and artificial methods } \\
\text { are already proven to be safe and } \\
\text { effective... }\end{array}$ & $\begin{array}{l}\text { a. combining natural } \\
\text { and artificial } \\
\text { means makes RLE } \\
\text { possible }\end{array}$ & 43 \\
\hline & 36 & 2 & $\begin{array}{l}\text { there is nothing natural about RLE - } \\
\text { making this seperation seems } \\
\text { pointless. }\end{array}$ & RLE is not natural & 31 \\
\hline
\end{tabular}

\section{The effect of face-to-face discussions}

The face-to-face discussion in stage 2 of the N-Reasons survey seems to have had little effect on participants with respect to changing their decisions. The majority seemed to persist in disagreeing with statements and reasons that support RLE. Out of the 40 participants who reconsidered their choice of reasons posted on each of the five questions in stage 3 , only five participants changed their responses.

\section{Discussion}

Attitudes toward radical life extension did not correspond to cultural attitudes indicated by responses to the World Values Survey questions. The proportion of agreement/disagreement to statements presented in each of the five questions varied across cultural groups and there 
tended to be more individuals who disagreed with radical life extension in all groups. Changes in responses after the discussion stage were not significant and most respondents maintained their prior views about the technology.

James Hughes (2010) has suggested that in biopolitics technoprogressives will not be able to forge consensus on issues related to human enhancement technologies (such as RLE) with right-bioconservatives because members of this latter group are ideologically opposed to the cultural values that members of the former group hold. Technoprogressives should rather strategically forge alliances with left-bioconservatives (e.g. greens and environmental activists) since this group shares some cultural values that their members favor. However, as suggested by responses to the five questions in our survey, there tends to be a mix from each of the cultural groups, categorized according to WVS categories, of those who agree and disagree with RLE as enhancement technology. Analyzing group responses, categorized according to certain cultural categories as biopolitical values or ideology, may not be as simple and straightforward as one could expect, since mixed preferences may be observed within groups who are asked to make decisions about certain technoethical issues. This is especially the case with new technologies that have not yet been subjected to the evolving societal response that creates certain moral routines or habits with regard to such technologies (Swierstra \& Rip, 2007). As is the case with new and emerging technologies, these will disturb previously created moral routines and elicit opposition across groups who will disagree with such routines and adopt new ones. It remains to be seen whether this kind of disturbance will create new moral routines or the old will be reasserted. The decision might hinge on whichever old or new moral routine emerges as a successful strategy in dealing with the new technology. In any case, the majority might adopt the successful strategy but this does not necessarily mean that the group will adopt pure strategies (Danielson, 2006). Our observation of mixed responses across cultural groups seems to support this possibility and the dominance of opposition to RLE as a new/emerging technology seems consistent with the disturbance of moral routines pattern suggested by Swierstra \& Rip (2007).

\section{Conclusion}

The categorization of cultural attitudes toward more familiar technologies may not correspond with attitudes to newer technologies since beliefs and values may need to adapt to new imagined situations that new technologies elicit. Moral understandings associated with familiar technoethical habits and beliefs are not necessarily carried over in relation to new technologies. This will depend on how successful these habits and beliefs are in dealing with new technologies. Existing resource-demanding life extension technologies used to treat the terminally ill and very old yield little gains such that people tend to oppose these technologies as wasteful if not lowest priority. When futuristic radical extension technologies appear to resemble the same cost-inefficiencies as are found in existing expensive treatments, similar responses could be expected. However, more cost-effective life extending technologies such as vaccinations, antibiotics, and preventive measures are associated with moral routines that seem to successfully support these technologies such that any resemblance found in new emerging technologies as RLE would be invoked as reasons to support or consider these new technologies. 


\section{Acknowledgements}

We wish to thank the following professors for giving us the opportunity to engage their students in this N-reasons survey on radical life extension: Dr. Francis Julius N. Evangelista, Dr. Benjamin M. Vallejo Jr., Dr. Rune Nydal and Dr. Siri Granum Carson. Dr. Evangelista helped us further by conducting the face-to-face discussion stage of the survey in his own class. Special thanks to Dr. Dan Weary for his help and suggestions in doing the quantitative analysis. Any errors, however, are our responsibility.

\section{Notes}

${ }^{1}$ The journal articles are (Oeppen \& Vaupel, 2002) and (de Grey, 2003).

${ }^{2}$ The articles included were (Central Intelligence Agency, 2013) and (Whitney, 1997).

${ }^{3}$ See (G. C. Daily, Ehrlich, \& Ehrlich, 1993) cf. (G. Daily, Ehrlich, \& Ehrlich, 1994).

${ }^{4}$ See (Gavrilov \& Gavrilova, 2010).

${ }^{5}$ See (Gunasekera, Tiller, Clements, \& Bhattacharya, 1986).

${ }^{6}$ See (Inglehart \& Welzel, 2010) and Appendix 2 for the list of statements included.

${ }^{7}$ Two of the authors, Alvarez and Mendoza, were guest instructors for a couple of classes that adopted the survey. Mendoza adopted the survey in a few his courses and Francis Evangelista adopted the survey in two of his critical thinking courses as application exercises to sharpen student skills in reasoning in relation to controversial issues.

${ }^{8}$ Selected key scenes from the CBC documentary on life extension Living Forever: The Longevity Revolution (2007) from The Nature of Things series with David Suzuki.

${ }^{9}$ Fig. 2 is adopted from WVS http://www.worldvaluessurvey.org. A copy of the map is available at http://www.iffs.se/wp-content/uploads/2012/12/Culture-Map_WVS5.jpg. Retrieved 24 April 2015.

${ }^{10}$ This is referred to in transcription literature as "naturalism" or "naturalized approach" to conversation analysis (Oliver, Serovich, \& Mason, 2005).

${ }^{11}$ The authors are not aware of similar surveys on RLE conducted among elderly cohorts but surveys on preference for Cardio Pulmonary Resuscitation (CPR) conducted among elderly participants seem to indicate that old people would prefer some form of life extension made possible, for example, by CPR. The following studies report that elderly people prefer CPR: (Cherniack, 2002); (Bruce-Jones, Roberts, Bowker, \& Cooney, 1996); (O'Brien, Grisso, Maislin, et al., 1995); (Gunasekera et al., 1986).

\section{References}

Bruce-Jones, P., Roberts, H., Bowker, L., \& Cooney, V. (1996). Resuscitating the elderly: what do the patients want? Journal of medical ethics, 22(3), 154-159. doi: 10.1136/jme.22.3.154

Central Intelligence Agency. (2013). Country Comparison: Life Expectancy at Birth The World Factbook Retrieved from https://www.cia.gov/library/publications/the-worldfactbook/rankorder/2102rank.html

Cherniack, E. P. (2002). Increasing use of DNR orders in the elderly worldwide: whose choice is it? Journal of medical ethics, 28(5), 303-307. doi: 10.1136/jme.28.5.303

Daily, G., Ehrlich, A., \& Ehrlich, P. (1994). Optimum human population size. Population and Environment, 15(6), 469-475. doi: 10.1007/bf02211719 
Daily, G. C., Ehrlich, A. H., \& Ehrlich, P. R. (1993). Optimum Human Population Size. Race, Poverty and Environment, 4(2).

Danielson, P. (2006). From artificial morality to NERD: models, experiments, and robust reflective equilibrium. In L. M. Rocha, L. S. Yaeger, M. A. Bedau, D. Floreano, R. L. Goldstone \& A. Vespignani (Eds.), Artificial Life X: Proceedings of the Tenth International Conference on the Synthesis and Simulation of Living Systems (pp. 4548). Cambridge: MIT Press.

Danielson, P. (2010). Designing a machine to learn about the ethics of robotics: the N-reasons platform. Ethics and information technology, 12(3), 251-261.

de Grey, A. D. N. J. (2003). The foreseeability of real anti-aging medicine: focusing the debate. Experimental Gerontology, 38(9), 927-934. doi: http://dx.doi.org/10.1016/S05315565(03)00155-4

Dragojlovic, N. (2013). Canadians' support for radical life extension resulting from advances in regenerative medicine. Journal of Aging Studies, 27(2), 151-158. doi: http://dx.doi.org/10.1016/j.jaging.2012.12.008

Dutta-Bergman, M. J. (2004). Primary Sources of Health Information: Comparisons in the Domain of Health Attitudes, Health Cognitions, and Health Behaviors. Health Communication, 16(3), 273-288. doi: 10.1207/s15327027hc1603_1

Funk, C., Lugo, L., Cooperman, A., Masci, D., Smith, G., Martinez, J. H., Fox, S. (2013). Living to 120 and Beyond: Americans' Views on Aging, Medical Advances and Radical Life Extension Retrieved from http://www.pewforum.org/files/2013/08/Radical-life-extension-full.pdf

Gavrilov, L. A., \& Gavrilova, N. S. (2010). Demographic Consequences of Defeating Aging. Rejuvenation Research, 13(2-3), 329-334.

Gunasekera, N. P. R., Tiller, D. J., Clements, L. T. S.-j., \& Bhattacharya, B. K. (1986). Elderly patients' views on cardiopulmonary resuscitation. Age and Ageing, 15(6), 364-368. doi: 10.1093/ageing/15.6.364

Hughes, J. (2010). Technoprogressive Biopolitics and Human Enhancement. In J. D. Moreno \& S. Berger (Eds.), Progress in Bioethics: Science, Policy, and Politics (pp. 163-188). Mass.: MIT Press.

Inglehart, R., \& Welzel, C. (2010). Changing Mass Priorities: The Link between Modernization and Democracy. Perspectives on Politics, 8(02), 551-567. doi:10.1017/S1537592710001258

O'Brien, L. A., Grisso, J., Maislin, G., \& et al. (1995). Nursing home residents' preferences for life-sustaining treatments. JAMA, 274(22), 1775-1779. doi: 10.1001/jama.1995.03530220041030

Oeppen, J., \& Vaupel, J. W. (2002). Broken Limits to Life Expectancy. Science, 296(5570), 1029-1031. doi: 10.1126/science. 1069675

Oliver, D. G., Serovich, J. M., \& Mason, T. L. (2005). Constraints and Opportunities with Interview Transcription: Towards Reflection in Qualitative Research. Social forces; $a$ scientific medium of social study and interpretation, 84(2), 1273-1289.

Partridge, B., Lucke, J., Bartlett, H., \& Hall, W. (2009). Ethical, social, and personal implications of extended human lifespan identified by members of the public. Rejuvenation Research, 12(5), 351-357.

Swierstra, T., \& Rip, A. (2007). Nano-ethics as NEST-ethics: patterns of moral argumentation about new and emerging science and technology. Nanoethics, 1(1), 3-20.

Whitney, C. R. (1997). Jeanne Calment, World's elder, dies at 122. New York Times, 8(5), 97. 


\section{Appendices}

Appendix 1: Five main survey questions

1. To what extent do you agree, disagree that RLE is a desirable goal for biomedical research?

2. If scientists could find safe and effective ways to radically extend life, which of the following means to RLE should we choose?

Option A: Only natural means, such as healthy diet and lifestyle.

Option B: Both natural and artificial means, such as pharmaceuticals, genetic engineering and nanotechnology.

3. Given the above contending projections [refers to the information presented in the vignette] of the consequences of RLE, should we be concerned about its effects on global population growth?

4. Would you avail of radical life extension if you were already in an elder care facility or in your advanced years, say, when you are already between $80-100$ ?

5. If you compare your own values and cultural traditions with the idea of radically extending life beyond 122 years, to what extent do you agree, disagree that RLE is compatible with your own deeply held beliefs?

Appendix 2: Cultural values questionnaire (20 statements based on World Values Survey)

List of statements in the cultural attitudes questionnaire (question number corresponds to the actual number assigned for data query):

$0 \mid$ God is very important to my life

4| I aim to give time for prayer, meditation or contemplation

$8 \mid$ Following customs and traditions handed down by my religion and family is important to me

10| I have a strong sense of national pride

12| There should be greater respect for authority

14| My family is very important to me

16| A child needs a home with both a father and a mother in order to grow up happily

18| A woman has to have children to be fulfilled

24| It is more important for a child to learn obedience and religious faith than independence and determination

26| Abortion should never be allowed

1| Men make better political leaders than women

7| I do not need to recycle things to protect the environment

9| I do not need to attend a meeting or sign a petition to protect the environment

11| A good income and safe job are more important than a feeling of accomplishment and working with people you like

15| When jobs are scarce, a man has more right to a job than a women

$17 \mid$ Government should ensure that everyone is provided for

19| Hard work is more important to teach a child than imagination

23| Tolerance is not of the most important things to teach a child

25| When jobs are scarce, employers should give priority to local people over immigrants

31| You have to be very careful about trusting people

Scores are assigned corresponding to choices:

Strongly Agree $=4$, Agree $=3$, Neutral=2, Disagree $=1$, Strongly Disagree $=0$. 
Total score between 21-40 on even-numbered statements indicates traditional values, total score of 0-20 secular-rational values. Total score between 21-40 on odd numbered statements indicates survival values, total score of 0-20 secular-rational values.

For example:

user 624 - even number score $=15$ (preference toward secular-rational values)

- odd number score $=14$ (preference toward self-expression values)

user 403 - even number score $=22$ (preference toward traditional values)

- odd number score $=28$ (preference toward survival values)

Appendix 3: Health attitudes questionnaire (11 statements derived from Dutta-Bergman (2004) study: the first five statements are from the Health consciousness measure and seven statements from the Health-oriented beliefs measure)

List of statements in the health attitudes questionnaire

0| Living life in the best possible health is very important to me

1| Eating right, exercising, and taking preventive measures will keep me healthy for life

2| My health depends on how well I take care of myself

3| I actively try to prevent disease and illness

4| I do everything I can to stay healthy

$5 \mid$ Eating a diet that is low in fat is important to me

6| I aim to eat lots of fruits, vegetables and grains

7| I aim to drink plenty of water every day

8| Taking vitamins and mineral supplements regularly is important

9| Not smoking cigarettes is important for my health

10| Not drinking alcohol or drinking in moderation is my goal

11| Maintaining a healthy body weight is important to me

Scores are assigned corresponding to choices:

Strongly Agree $=4$, Agree=3, Neutral=2, Disagree $=1$, Strongly Disagree $=0$.

For example:

user 624 total score $=25$ (moderately health-conscious)

user 757 total score $=45$ (very health-conscious)

Very health conscious $=$ score of 37 to 48

Moderately health conscious $=$ score of 24 to 36

Not so health conscious $=$ score of 12 to 23

Not health conscious $=0$

How health-conscious were the groups in this survey?

Results of the health attitudes questionnaire (see Chart 13 below) showed that $50 \%$ of all participants were moderately health-conscious, $49 \%$ were very health conscious, and only $1 \%$ were not so health-conscious.

Chart 13. Percent of participants indicating degree of being health-conscious $[N=326]$

Not so health-consicous $\quad$ Moderately health-conscious $\quad$ Very health-conscious 